\title{
Behavioral and Biomedical Combination Strategies for HIV Prevention
}

\author{
Linda-Gail Bekker ${ }^{1,2}$, Chris Beyrer ${ }^{3}$, and Thomas C. Quinn ${ }^{4}$ \\ ${ }^{1}$ The Desmond Tutu HIV Centre, Institute of Infectious Disease and Molecular Medicine, University \\ of Cape Town, Cape Town 7925, South Africa \\ ${ }^{2}$ Department of Medicine, University of Cape Town, Cape Town 7925, South Africa \\ ${ }^{3}$ Department of Epidemiology, Johns Hopkins Bloomberg School of Public Health, Baltimore, Maryland 21205 \\ ${ }^{4}$ Section on International HIV/STD Research, National Institute of Allergy and Infectious Diseases, National \\ Institutes of Health, Bethesda, Maryland 20892 \\ Correspondence: Linda-gail.bekker@hiv-research.org.za
}

\begin{abstract}
Around 2.5 million people become infected with HIV each year. This extraordinary toll on human life and public health worldwide will only be reversed with effective prevention. What's more, in the next few years, it is likely at least, that no single prevention strategy will be sufficient to contain the spread of the disease. There is a need for combination prevention as there is for combination treatment, including biomedical, behavioral, and structural interventions. Expanded HIV prevention must be grounded in a systematic analysis of the epidemic's dynamics in local contexts. Although $85 \%$ of HIV is transmitted sexually, effective combinations of prevention have been shown for people who inject drugs. Combination prevention should be based on scientifically derived evidence, with input and engagement from local communities that fosters the successful integration of care and treatment.
\end{abstract}

$\mathrm{H}$ istory has taught us that the way to eradicate a global viral epidemic is to design, mass produce, and then systematically vaccinate the population at risk with an effective prophylactic vaccine (Fifty-Fifth World Assembly 2008; http://www.who.int/mediacentre/news/ releases/releasewha01/en/index.html). Past experience has also shown that the path to an effective AIDS vaccine may be long and complicated (Nabel 2001; Barouche 2008). Although the modest RV144 or "Thai" vaccine trial efficacy results in 2009 provided the first hope that a prophylactic HIV vaccine may be possible (Rerks-Ngarm et al. 2009), with almost 60 million men, women, and children having been infected and more than 25 million attributable deaths, 30 years of this epidemic has taken a monstrous toll. More worrying still, modeling exercises have indicated that staggering numbers of new infections may occur given current infection rates. The world may be facing 20-60 million new HIV infections in the 15-20 years it may take to develop and evaluate a highly efficacious prophylactic vaccine. Such alarming projections emphasize the urgency of finding effective alternative approaches to prevention more immediately (Legakos and Gable 2008).

Editors: Frederic D. Bushman, Gary J. Nabel, and Ronald Swanstrom

Additional Perspectives on HIV available at www.perspectivesinmedicine.org

Copyright (C) 2012 Cold Spring Harbor Laboratory Press; all rights reserved; doi: 10.1101/cshperspect.a007435

Cite this article as Cold Spring Harb Perspect Med 2012;2:a007435 
L.-G. Bekker et al.

King Holmes has proposed a synergistic combination of sociobehavioral and medical interventions and coined the phrase highly active retroviral prevention (HARP). He further stated "only fools today still advocate a single method of HIV prevention" (Vandenbruaene 2007). Coates and colleagues captured this concept previously (Fig. 1) (Coates et al. 2008).

The emphasis in prevention research in 2011 has therefore shifted to the design and evaluation of combination prevention packages. The justification for this is summarized in Table 1.

A challenge for researchers in the HIV prevention field is to design combination packages that are feasible, effective, affordable, community- and population-specific, and acceptable. This article examines the available biomedical and behavioral interventions and the evidence of their suitability for inclusion in combination prevention packages.

\section{KNOW YOUR EPIDEMIC, KNOW YOUR RESPONSE}

It is likely that prevention packages will not be a "one size fits all endeavor" and ideal menus will need to be tailored for specific behaviors, regions, and risk categories. This requires that physicians and public health workers know their local populations and the basis for transmission and thus tailor responses accordingly.
The rapidly changing face of the epidemic calls not only for increased epidemiologic HIV transmission and behavioral surveillance but also for nuanced investigation that accounts for preference, social, cultural, and gender contexts. To this end, UNAIDS has launched a program entitled "know your epidemic, know your response" which encourages country-led investigation of the relevant drivers and risk behaviors (UNAIDS 2007; Wilson and Halperin 2008).

\section{Which Level of Evidence?}

Padian and colleagues (2010) have examined all randomized controlled trials with HIV transmission as an endpoint performed in the last 2 decades (summarized and updated in Table 2) and asked what types of evidence will be considered in the selection of interventions in prevention packages of the future. Public health agencies have long recognized the shortfalls posed by relying solely on randomized controlled trial (RCT) data and have consequently developed guidance that also considers a variety of other data sources (Padian et al. 2010). HIV prevention researchers may need to adopt similar strategies. Furthermore, a clear understanding of how partially efficacious interventions may be combined for synergistic or additive effect remains a challenge (Piot et al. 2008).

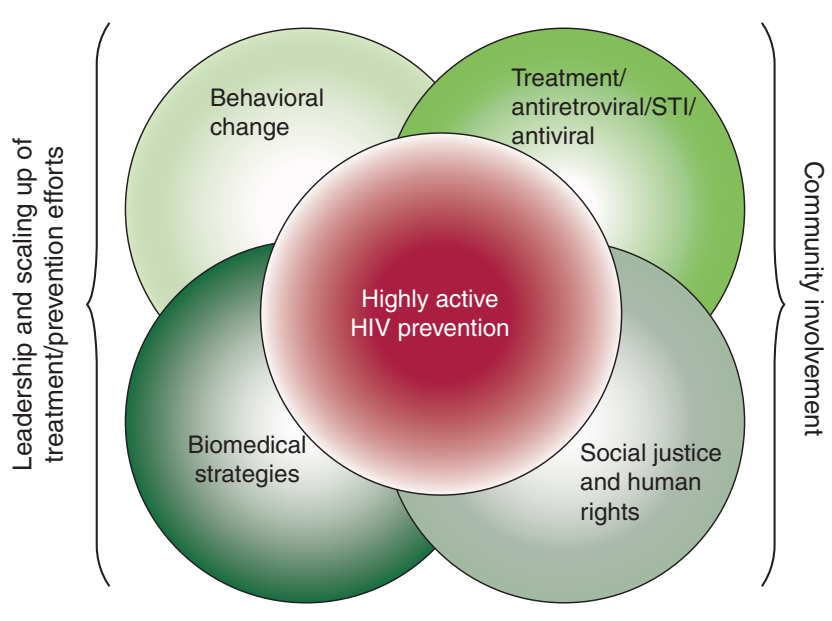

Figure 1. Highly active HIV prevention, a term coined by King Holmes, University of Washington School of Medicine, Seattle, WA. (STI) Sexually transmitted infections (Coates and Gable 2008). 
Table 1. Reasons for a shift to prevention packages

\begin{tabular}{|c|c|c|}
\hline Concept & Reason & Reference \\
\hline 1. & $\begin{array}{l}\text { It is clear from results of recent trials that there will } \\
\text { be no single "magic bullet" for HIV prevention } \\
\text { in the near term. }\end{array}$ & Padian et al. 2010 \\
\hline 2. & $\begin{array}{l}\text { Interventions with modest levels of effect might } \\
\text { lead to more substantial efficacy overall if } \\
\text { combined. }\end{array}$ & Auerbach and Coates 2000 \\
\hline 3. & $\begin{array}{l}\text { Current biomedical interventions are affected by } \\
\text { human behavioral factors (adherence, risk } \\
\text { compensation) and will rely on sociobehavioral } \\
\text { interventions to strengthen effectiveness. }\end{array}$ & Padian et al. 2008 \\
\hline 4. & $\begin{array}{l}\text { Biomedical interventions are being offered } \\
\text { in addition to an already relatively } \\
\text { robust prevention package, including } \\
\text { regular HIV testing, risk reduction counseling, } \\
\text { latex condoms, and postexposure } \\
\text { chemoprophylaxis. }\end{array}$ & $\begin{array}{l}\text { Grant et al. 2010; Karim } \\
\quad \text { et al. } 2010\end{array}$ \\
\hline 5. & $\begin{array}{l}\text { In most of the recently reported randomized } \\
\text { controlled HIV prevention trials, there is some } \\
\text { reduction in reported sexual risk over time and a } \\
\text { lower than expected HIV incidence in the trial } \\
\text { population overall, even when the modality } \\
\text { under investigation has not shown any positive } \\
\text { effect. }\end{array}$ & Padian et al. 2010 \\
\hline
\end{tabular}

\section{BEHAVIORAL STRATEGIES}

Efforts to modify sexual and drug-using human behaviors to reduce HIV risk have fallen short in the last 2 decades. Behavioral strategies have been defined as interventions to "motivate behavioral change in individuals and social units by use of a range of educational, motivational, peer-led, skill-building approaches as well as community normative approaches" (Coates and Gable 2008). A list of some available behavioral strategies is given in Table 3. The first successful examples of behavior change that led to decreased HIV transmission incidence were reported in men who have sex with men (MSM) (Winkelstein et al. 1988; Kippax and Race 2003). Subsequently, a number of countries have attributed decreases in HIV incidence to changes in sexual behavior, including Brazil, Cote d'Ivoire, Kenya, Uganda, Malawi, Tanzania, Zimbabwe, Burkino Faso, Namibia, and Swaziland (Stoneburner and Low-Beer 2004; Slutkin et al. 2006).

\section{Behavioral Intervention Research}

The HIV literature is full of behavioral interventional and observational studies in a variety of settings and target groups, most of which have not objectively altered HIV transmission or acquisition rates. Seven randomized trials of behavioral interventions, described by Padian and colleagues, summarized in Table 4, showed neither benefit nor harm (Padian et al. 2010). Project EXPLORE is the only interventional study for HIV behavior with an HIV infection endpoint. Using a counseling intervention to reduce HIV incidence, the average follow-up was $3.25 \mathrm{yr}$ and HIV acquisition was reduced by $18.2 \%$ in the experimental arm, but this effect compared with controls was insignificant. On more careful examination, there were more dramatic effects on HIV incidence in the first year $(39 \%)$, but this effect was lost over time. There is a recurring theme in the literature that behavioral change is hard to maintain (Koblin et al. 2004; Karim et al. 2010). 
L.-G. Bekker et al.

Table 2. Results of 40 randomized controlled trials reporting on 42 interventions to prevent sexual transmission of HIV

\begin{tabular}{|c|c|c|c|c|}
\hline \multirow[b]{2}{*}{ Type of intervention } & \multicolumn{3}{|c|}{ HIV prevention efficacy } & \multirow[b]{2}{*}{ Total } \\
\hline & $\begin{array}{l}\text { Positive effect (significantly } \\
\text { reduced HIV incidence } \\
\text { compared with control) }\end{array}$ & $\begin{array}{l}\text { Adverse effect (significantly } \\
\text { increased HIV incidence } \\
\text { compared with control) }\end{array}$ & $\begin{array}{c}\text { No effect } \\
\text { (either way) }\end{array}$ & \\
\hline Behavioral & - & - & 7 & 7 \\
\hline Microfinance & - & - & 1 & 1 \\
\hline Diaphragm & - & - & 1 & 1 \\
\hline Vaginal microbicides & 1 & 1 & 11 & 13 \\
\hline $\begin{array}{l}\text { Preexposure } \\
\text { prophylaxis }\end{array}$ & 1 & - & 2 & 3 \\
\hline Male circumcision & 3 & - & 1 & 4 \\
\hline $\begin{array}{l}\text { Sexually transmitted } \\
\text { infection }(\mathrm{STI}) \\
\text { treatment }\end{array}$ & 1 & - & 8 & 9 \\
\hline Vaccine & 1 & - & 3 & 4 \\
\hline $\begin{array}{l}\text { Antiretroviral therapy } \\
\text { (ART) in } \\
\text { discordancy }\end{array}$ & 1 & - & - & 1 \\
\hline Total & 8 & 1 & 34 & 43 \\
\hline
\end{tabular}

Data adapted from Padian 2010.

\section{Behavioral Intervention Programming}

Auerbach and Coates (2008) state "behavioral strategies are necessary but not sufficient to reduce HIV transmission, but are essential in a comprehensive HIV prevention strategy. Behavioral strategies themselves need to be combinations of approaches at multiple levels of influence." The list of possible behavioral interventions that have been identified over this time is long (Table 3), and inclusion of any component in a combination prevention package would depend on the target population and the risk activity.

The slogan, the "ABC of HIV prevention" was apparently first coined as part of a prevention campaign in Botswana in the late 1990s (Fig. 2). It was well known by then that individuals could reduce their risk of becoming HIV infected through sexual transmission; however, an "inappropriate and ineffective" emphasis on "abstinence only" in prevention programming was counterproductive in many settings where HIV risk occurred (Coates et al. 2008; Collins et al. 2008).

\section{The Need for Combination Prevention}

Most forms of prevention need continual behavior modification to be effective. This effect was highlighted in two efficacy trials of preexposure prophylaxis (PrEP), one oral (Grant et al. 2010) and one topical (Karim et al. 2010). Both showed modest efficacy overall but improved efficacy in those participants who were most adherent. Future combination prevention packages are likely to contain one or more of these

Table 3. A list of some behavioral strategies

Sexual debut delay

Sexual partner reduction

Consistent condom usage

HIV counseling and testing

Sexual abstinence

Monogamy

Biomedical intervention uptake and consistent usage

Adherence to harm reduction strategies

Decreased substance use

Data adapted from Coates and Gable 2008. 
Table 4. Randomized controlled trials assessing behavioral HIV prevention interventions

\begin{tabular}{|c|c|c|c|c|}
\hline \multirow[b]{2}{*}{ Author } & \multirow[b]{2}{*}{ Citation } & \multirow{2}{*}{$\begin{array}{l}\text { Brief description of } \\
\text { participants and study }\end{array}$} & \multicolumn{2}{|c|}{$\begin{array}{l}\text { Risk-taking behavior } \\
\text { decreased during } \\
\text { the study? }\end{array}$} \\
\hline & & & Intervention & Control \\
\hline $\begin{array}{l}\text { Kamali et al. } \\
2003\end{array}$ & $\begin{array}{l}\text { Syndromic management } \\
\text { of sexually trans- } \\
\text { mitted infections and } \\
\text { behaviour change } \\
\text { interventions on } \\
\text { transmission of HIV-1 } \\
\text { in rural Uganda: A } \\
\text { community } \\
\text { randomised trial. }\end{array}$ & $\begin{array}{l}\text { Adults in rural Uganda were } \\
\text { randomized to syndromic STI } \\
\text { management, behavioral } \\
\text { interventions in combination with } \\
\text { syndromic STI management and } \\
\text { routine care and community } \\
\text { development services. The primary } \\
\text { outcome was HIV-1 incidence. } \\
\text { Secondary outcomes were incidence } \\
\text { of STIs and markers of behavioral } \\
\text { change. }\end{array}$ & Yes & Yes \\
\hline $\begin{array}{l}\text { Koblin et al. } \\
2004\end{array}$ & $\begin{array}{l}\text { Effects of a behavioural } \\
\text { intervention to reduce } \\
\text { acquisition of HIV } \\
\text { infection among men } \\
\text { who have sex with } \\
\text { men: The EXPLORE } \\
\text { randomised } \\
\text { controlled study. }\end{array}$ & $\begin{array}{l}\text { Men that have sex with men. The } \\
\text { experimental intervention consisted } \\
\text { of } 10 \text { one-on-one counseling } \\
\text { sessions followed by maintenance } \\
\text { sessions every } 3 \text { mo. Outcomes } \\
\text { include HIV incidence and } \\
\text { assessment of behavioral change, } \\
\text { including occurrence of unprotected } \\
\text { receptive anal intercourse with HIV- } \\
\text { positive and unknown-status } \\
\text { partners. }\end{array}$ & Yes & Yes \\
\hline $\begin{array}{l}\text { Ross et al. } \\
2007\end{array}$ & $\begin{array}{l}\text { Biological and } \\
\text { behavioral impact of } \\
\text { an adolescent sexual } \\
\text { health intervention in } \\
\text { Tanzania: A } \\
\text { community- } \\
\text { randomized trial. }\end{array}$ & $\begin{array}{l}\text { Youth in Tanzania. The intervention } \\
\text { had four components: Community } \\
\text { activities; teacher-led, peer-assisted } \\
\text { sexual health education in years 5-7 } \\
\text { of primary school; training and } \\
\text { supervision of health workers to } \\
\text { provide "youth-friendly" sexual } \\
\text { health services; and peer condom } \\
\text { social marketing versus standard } \\
\text { activities. Impacts on HIV incidence, } \\
\text { STI symptoms, as well as knowledge, } \\
\text { reported attitudes, and other sexual } \\
\text { health and behavioral outcomes } \\
\text { were measured. }\end{array}$ & $\mathrm{NA}^{\mathrm{a}}$ & $\mathrm{NA}^{\mathrm{a}}$ \\
\hline $\begin{array}{l}\text { Corbett et al. } \\
2007\end{array}$ & $\begin{array}{l}\text { HIV incidence during a } \\
\text { cluster-randomized } \\
\text { trial of two strategies } \\
\text { providing voluntary } \\
\text { counseling and testing } \\
\text { at the workplace, } \\
\text { Zimbabwe. }\end{array}$ & $\begin{array}{l}\text { Business employees in Zimbabwe. } \\
\text { Comparison of voluntary counseling } \\
\text { and testing (VCT) when counseling } \\
\text { and rapid testing were available } \\
\text { onsite versus using prepaid vouchers } \\
\text { for an external provider (which was } \\
\text { the standard VCT). The main } \\
\text { measured outcomes were rate of HIV } \\
\text { incidence and VCT uptake. }\end{array}$ & NR & NR \\
\hline
\end{tabular}


L.-G. Bekker et al.

Table 4. Continued

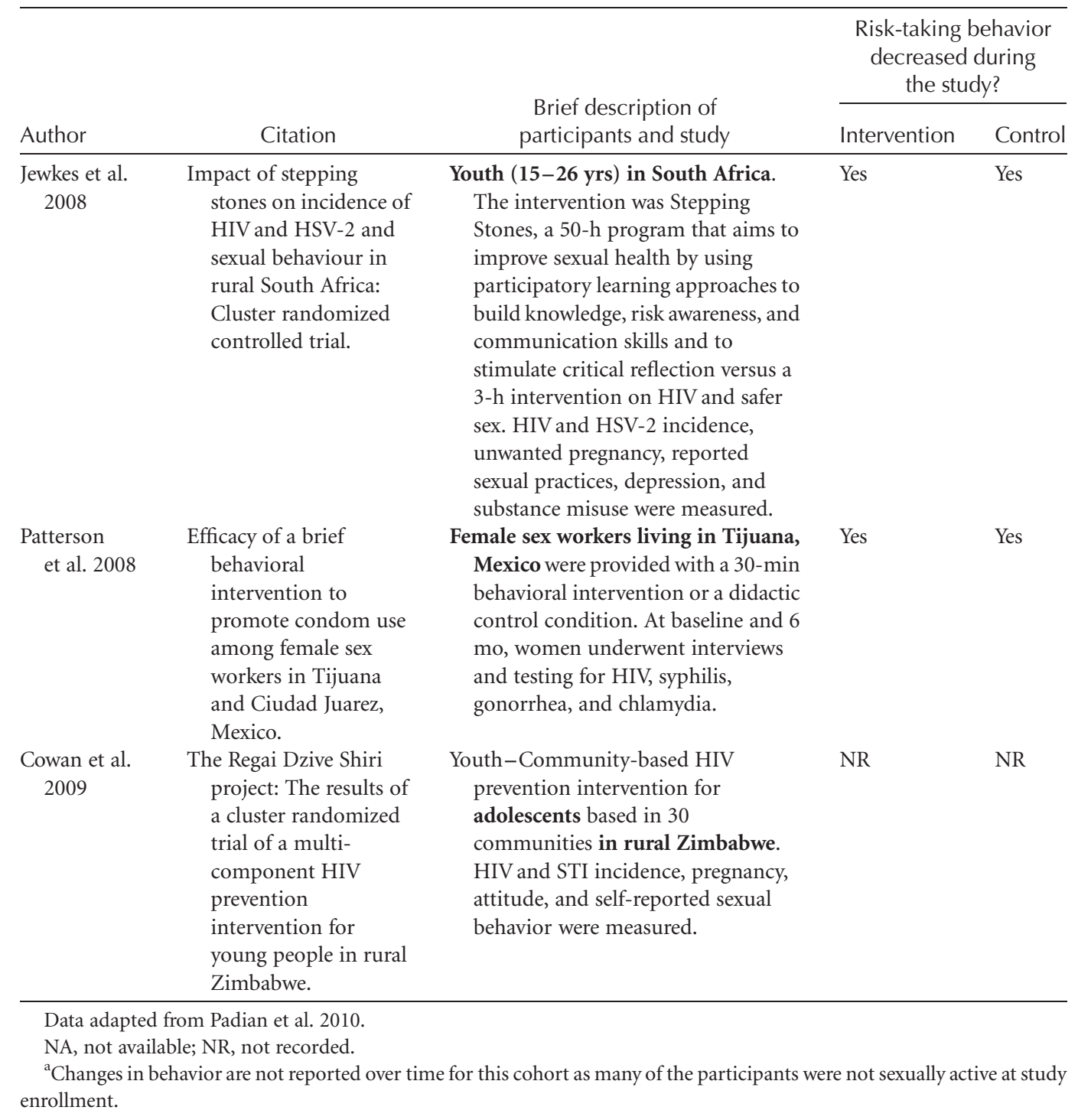

biomedical interventions: vaginal microbicides providing a female-initiated methodology and oral PrEP as an alternative for those at risk for HIV exposures other than via the vaginal mucosa. Research is currently under way on rectal microbicides (Microbicide Trials Network 2011). The challenge will be to design prevention studies that embrace this integrated model of combined interventions. In addition, it will be important to monitor at the community level what happens when the combination intervention is scaled up (Piot et al. 2008).

\section{CONDOMS}

Intact latex and polyurethrane condoms have been shown in vitro to be impenetrable to particles the size of sexually transmitted pathogens (Lyle et al. 1997). When male condoms are used consistently, their effectiveness in reducing HIV transmission can be as high as 95\% (Pinkerton et al. 1997). In most countries with generalized epidemics, condoms are actively promoted for all sexually active individuals as part of a comprehensive prevention approach despite 


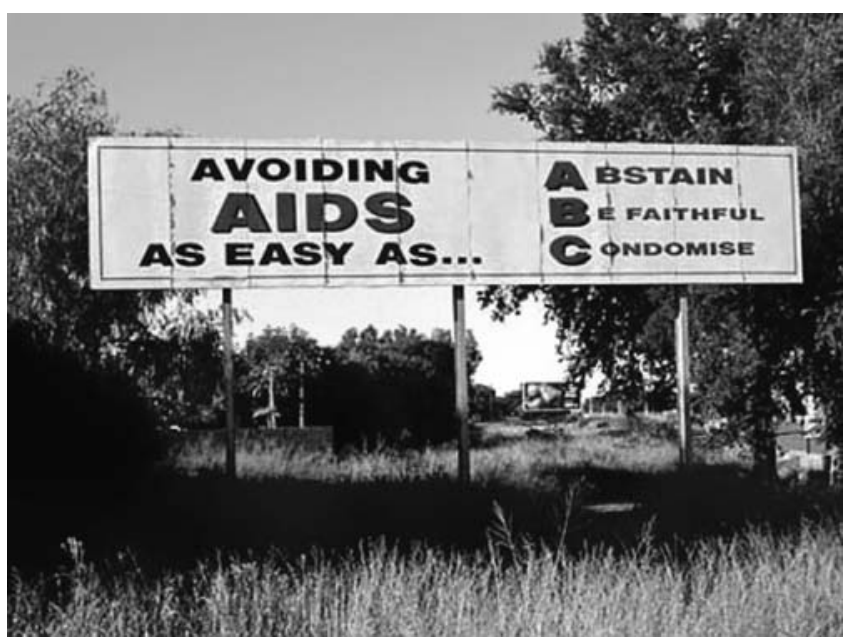

Figure 2. The "ABC" HIV prevention campaign. Billboard in Botswana. Sexual HIV risk could be avoided altogether by avoiding any sexual activities that could cause transmission of HIV $(A$, Abstain) or through avoiding sexual intercourse other than with a mutually faithful uninfected partner $(B$, Be faithful) or through the correct and consistent use of condoms ( $C$, Condomise). the social, economic, and psychological factors that limit their consistent use.

Several longitudinal cohort studies of serodiscordant couples estimated the effectiveness of male condoms for prevention of HIV transmission at around 85\% (Weller et al. 2002). A study in MSM showed $76 \%$ efficacy in HIV prevention if used consistently (Golden 2006). The type of lubricant used, rather than strength of condom, was reported to be more important in safe usage of condoms in MSM (Harding et al. 2000). One of the most cited examples of how campaigns and policy can markedly increase male condom uptake is the much cited " $100 \%$ condom use policy" in Thailand involving, in particular, the military and sex workers. Following an increase in condom usage from just over $10 \%$ in 1989 to $>90 \%$ by 1993 in sex workers, incidence of new sexually transmitted infections (STIs) was seven times lower and HIV incidence was 50\% lower (UNAIDS 2000). Similar success has been described in other female sex worker populations from other parts of the world (Weir et al. 1998).

Condom use and effectiveness at the population level is not well established. Demographic and health surveys from Latin America and Africa have reported increased usage of male condoms in recent years (Kerrigan et al. 2006; Shisana et al. 2009; Rehle et al. 2010). Recent encouraging reports suggest that the use of mass media and creative condom social marketing to change attitudes and increase use have been successful (Foss et al. 2007).

\section{The Female Condom}

Female condoms were developed to provide a female-controlled biomedical HIV prevention method. Also made from polyurethrane or latex, they provide a physical barrier to HIV particles and prevent exposure to genital secretions containing HIV (Drew et al. 1990). No specific trials have been conducted to assess the efficacy of the female condom to prevent HIV infection, although impact on STI rates have been reported (French et al. 2003). Although the male partner is not unaware of the female condom, it does provide a prevention strategy that is less dependent on male willingness. Cost and mechanical difficulties have been cited as reasons for limited uptake (Galvao et al. 2005), but newer designs are easier to use, can be reused (Thomsen et al.2006), and are made of materials that improve sensation with the promise of enhancing acceptability, uptake, and cost (Coffey et al. 2006). There are increasing reports of female condoms being used for HIV prevention in anal sex (http://doh.dc.gov/doh/cwp/ view,a,1371,q,602647,dohNav_GID,1839,doh Nav, |33815|,,.asp).

The perception exists that condom use indicates high-risk sexual partnerships associated 
L.-G. Bekker et al.

with infidelity and infection. More than $2 / 3$ of new infections occur in sub-Saharan Africa (SSA) between heterosexual cohabiting partners, and data from Rwanda and Zambia suggest that $60 \%-95 \%$ of new infections occur between married couples living together (Dunkle et al. 2008). In this setting, consistent condom use is challenging and couples-based HIV testing and counseling may have a greater role (The Voluntary HIV-1 Counseling and Testing Study Group 2000).

Additionally, there is a gap between supply and demand of condoms, especially in the developing world. Ideally, condoms should be free in these environments as research suggests even extremely low prices are a barrier to use (UNAIDS 2009). The United Nations Population Fund (UNFPA) estimated that at least 13.1 billion condoms are required annually to reduce the spread of HIV (UNFPA 2007). In 2008, < 15\% of this target was distributed globally.

\section{HIV COUNSELING AND TESTING}

HIV counseling and testing (HCT) services are important entry points for prevention and care. Studies from different countries have shown that individuals take precautions to protect their partners once they know they are HIV positive (Sweat et al. 2000; Allen et al. 2003), and modeling studies have found HCT to offer substantial clinical benefits and to be cost effective even in settings where linkage and access to care is limited (Walensky et al. 2009).

The past decade has seen a rapid global scale-up of HCT (WHO 2009; Kranzer et al. 2010). HCT uptake is associated with a range of sociodemographic factors and identifying characteristics of individuals who have never been tested is important to develop services targeted at first-time testers and thus to achieve universal access to HCT (Khumalo-Sakutukwa et al. 2008; Helleringer et al. 2009).

Sexually active individuals in high HIV prevalence settings are at continuous risk of infection and should therefore be tested at regular intervals. The World Health Organization (WHO) recommends annual testing in these settings, and a recent study from South Africa found annual screening to be very cost effective even in the Western Cape, the province with the lowest rates of HIV infection in South Africa (Walensky et al. 2009).

\section{Evidence for HCT Role in Prevention}

Studies have shown that many infected persons decrease high-risk sexual or needle-sharing behaviors once they are aware of their positive HIV status. The majority of this research is from high-income countries, with the strongest evidence for behavior change within discordant couples who also received counseling. Most studies that have assessed the effect of HCT on sexual behavior have focused on the change in behavior over periods of less than a year (Denison et al. 2008).

The challenge is to increase testing coverage and identify those who are positive for care (Kranzer et al. 2010). Strategies to increase testing have included national campaigns, provider-initiated counseling such as has been implemented in Botswana (Bateganya et al. 2007), couples counseling services, and community-level campaigns such as Project Accept (Fig. 3) (Khumalo-Sakutukwa et al. 2008). These alternative strategies not only increase coverage but ensure inaccessible populations such as men, the working population, and asymptomatic HIV-infected individuals are also tested (Matovu and Makumbi 2007). The role of incentives to increase testing coverage is also being investigated in a number of settings and populations (http://www.cgdev.org/con tent/publications/detail/1424161).

\section{PREVENTION WITH POSITIVES}

Traditional prevention has been thought of as protecting individuals from becoming HIV infected. Positive prevention embraces the concept that individuals who have tested positive may be helped to avoid spreading the infection further. Positive prevention also recognizes that infected individuals may want to remain sexually active and may wish to have children, both of which can be done with minimized harm to others (PEPFAR Prevention 2008). 


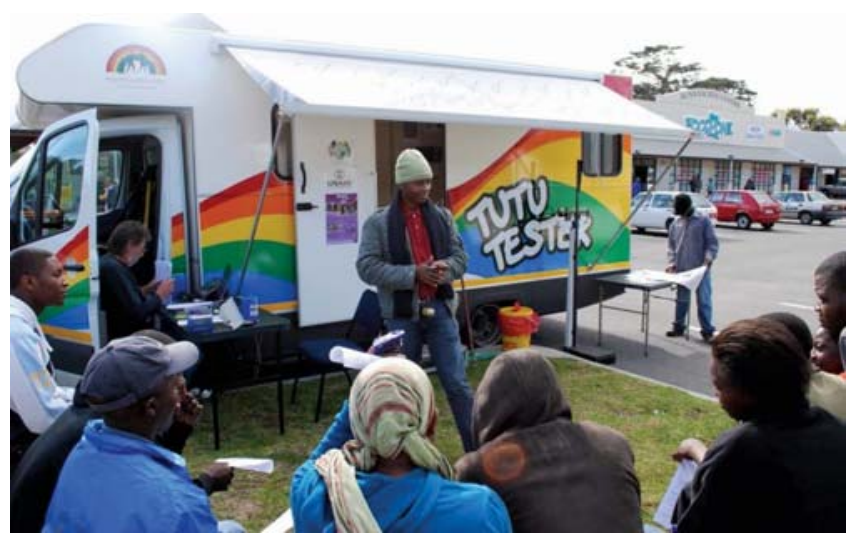

Figure 3. Testing coverage can be markedly increased by using a variety of nontraditional venues and outlets such as household campaigns, high-risk venues, work environments, and community-based mobile testing units such as The Tutu Tester is a mobile testing service operating in Cape Town, South Africa (van Schaik et al. 2010).

\section{Research in Positive Prevention}

Antiretroviral therapy (ART) has dramatically reduced the morbidity and mortality of HIV infection through sustained reduction in HIV viral replication (De Cock et al. 2009). This reduction in HIV viral load (plasma HIV ribonucleic acid [RNA] levels) reduces infectiousness in the infected individual and, as a result, susceptibility for the noninfected partner (Musicco et al. 1994).

\section{Evidence for Reduced HIV Transmission}

Viral load is the single greatest risk factor for all transmission modes. ART can reduce the plasma and genital HIV viral load in the infected individual to undetectable levels (Granich et al. 2010). In a study of 415 HIV serodiscordant couples in Uganda, $21.7 \%$ of the initially uninfected partners became infected over 30 months of follow-up, translating to a transmission rate of approximately 12 infections per 100 person years (Fig. 4) (Quinn et al. 2000). No transmission events occurred in those couples in which the infected partner had a plasma HIV-1 RNA level of less than 1500 copies $/ \mathrm{mL}$, and the transmission risk increased as plasma HIV-1 RNA levels increased. For every 10-fold increase in viral load, there was a greater than twofold risk of transmission. This was similarly shown in HIVserodiscordant couples in Zambia (Fideli et al. 2001). Plasma HIV-1 RNA levels generally correlate positively with the concentration of HIV in genital secretions, rectal mucosa, and saliva, although inflammation can stimulate local replication (Cu-Uvin et al. 2000; Lampinen et al. 2000; Shugars et al. 2000). Other studies have shown that transmission events may be observed at a very low plasma HIV-1 RNA level, suggesting that plasma viral load is not the only determinant of transmission (Vernazza et al. 2000; Tovanabutra et al. 2002).

\section{Clinical Research in Discordant Couples}

The outcomes of two retrospective clinical studies that showed the benefit of ART on HIV transmission (Musicco et al. 1994; Castilla et al. 2005) have been corroborated by the recent release of early results from a randomized trial, known as HPTN 052. The deferred treatment study arm was prematurely halted after a scheduled interim review by an independent Data and Safety Monitoring Board (DSMB) that concluded that initiation of ART by HIVinfected individuals substantially protected their HIV-uninfected sexual partners from acquiring HIV infection, with a 96\% reduction in risk of HIV transmission. The study enrolled 1763, mostly heterosexual discordant couples in which the infected index case was ART-naive and had a CD4 T-cell count of 350-550 cells/ $\mathrm{mm}^{3}$. Treatment was commenced at 250 cells/ $\mathrm{mm}^{3}$ in the control or "treatment deferment" arm (Cohen et al. 2011). 
L.-G. Bekker et al.

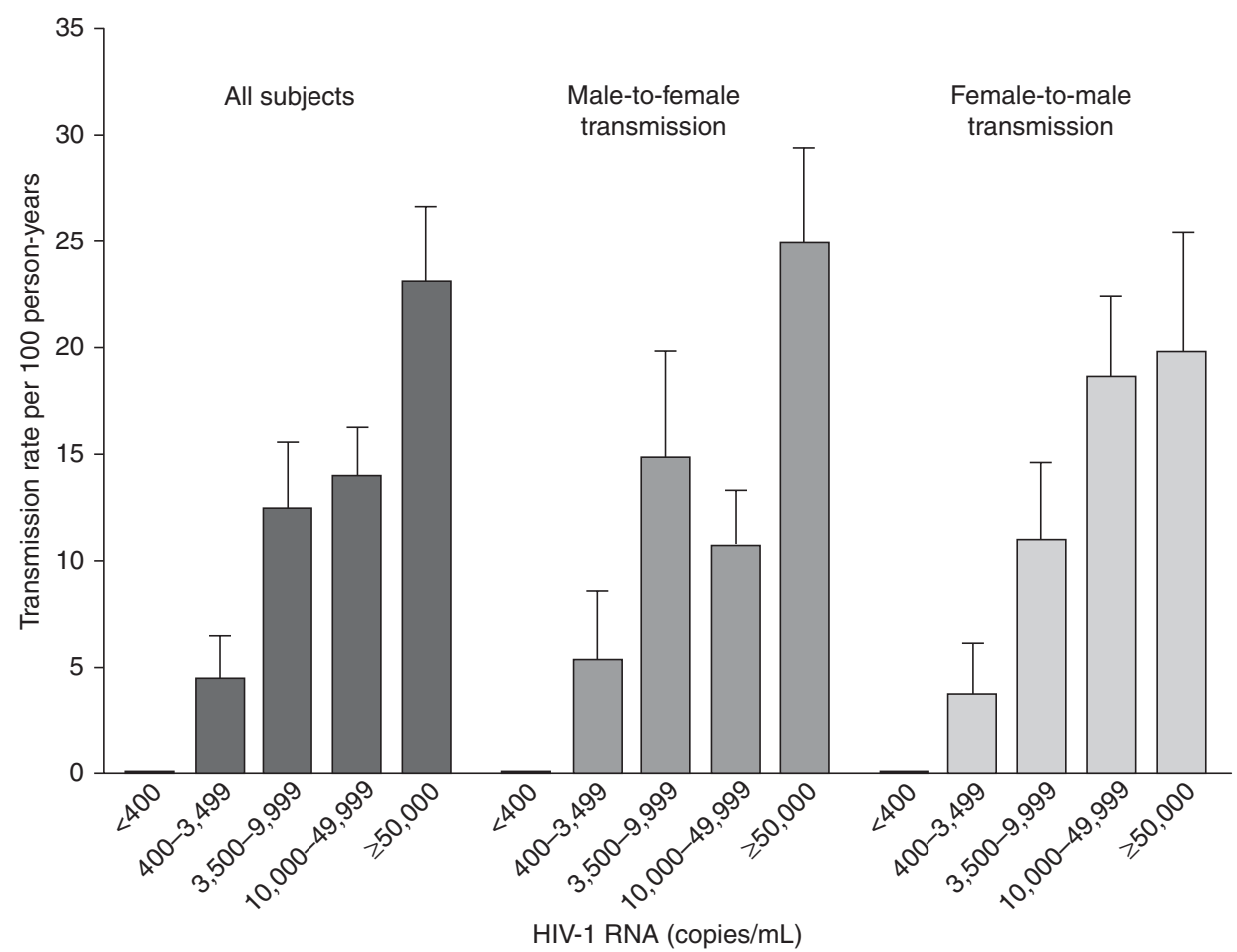

Figure 4. HIV transmission is dependent on plasma viral load. Mean $(+\mathrm{SE})$ rate of heterosexual transmission of HIV-1 among 415 couples, according to the sex and the serum HIV-1 RNA level of the HIV-1-positive partner (Quinn et al. 2000). At baseline, among the 415 couples, 228 male partners and 187 female partners were HIV-1positive. The limit of detection of the assay was $400 \mathrm{HIV}-1$ RNA copies per milliliter. For partners with fewer than $400 \mathrm{HIV}-1$ RNA copies per milliliter, there were zero transmissions.

\section{Mathematical Models and Population-Level Impact}

Extrapolating from this result, reduction of viral load within a population would likely lower the rate of heterosexual transmission within that population. Substantial reduction in the number of anticipated HIV cases in concentrated epidemics of injection drug users and MSM have been reported in at least two populationbased studies of HIV incidence before and after the availability of ART (Katz et al. 2002; Fang et al. 2004; Porco et al. 2004). Mathematical models have been used to predict the ability of HIV treatment to reduce HIV incidence and prevalence. In a model generated by Gray et al. from the Ugandan transmission study data, ART would be predicted to reduce incident HIV by $80 \%$ (Gray et al. 2001). Conversely, others have argued that ART could not reduce HIV prevalence in resource-constrained regions (Baggaley et al. 2006). More recently, this has led to the concept of "Test and Treat," modeled by Granich et al. (2009), which espouses universal HIV testing with immediate commencement of ART, regardless of clinical or immune status. This controversial model, based on the South African epidemic, with annual testing, heterosexual transmission, and a number of other assumptions, reported that immediate ART initiation could reduce HIV incidence by $95 \%$ over a 10 year period. To be considered, of course, are the cost and operational challenges as well as the risk of drug resistance and toxicity (Padian et al. 2008).

However, this shift from a focus on downstream therapeutic application of ART to more upstream preventive benefits of eliminating 
HIV transmission has received considerable interest. A number of community-based feasibility studies are under way or planned in the United States and Southern Africa, and it is envisaged that definitive randomized trials will be designed and executed in the next $5-10$ years.

\section{MALE CIRCUMCISION}

Practiced since at least the Sixth Dynasty (2345-2181 B.C.), approximately 30\%-34\% of adult men globally are circumcised (Padian et al. 2008). Male circumcision was first proposed in 1986 as an intervention to reduce risk of HIV acquisition (Fink 1986). Ecological and observational studies had shown that, in regions where HIV transmission is predominantly heterosexual, the prevalence of HIV and of male circumcision are inversely correlated (Bailey et al. 2001). The prevalence of HIV has been shown to be significantly higher in uncircumcised than in circumcised men in more than 30 cross-sectional studies, and a number of prospective studies have shown a protective effect, ranging from $48 \%$ to $88 \%$ (Bongaarts et al. 1989; Moses et al. 1990; Caldwell and Caldwell 1996; Gray et al. 2000; Reynolds et al. 2004; Buchbinder et al. 2005). A meta-analysis of studies from SSA reported an adjusted relative risk of 0.42 (95\% CI $0.34-0.54)$ in all circumcised men, with a stronger adjusted relative risk of $0.29(0.20-0.41)$ in circumcised men who were at higher risk of acquiring HIV (Weiss et al. 2000).

\section{RCTs}

To definitively document the protective associations of circumcision, three RCTs were designed and undertaken in three sub-Saharan countries: South Africa, Kenya, and Uganda. Design and results are presented (Table 5). A total of 11,054 HIV-negative men aged between 15 and $49 \mathrm{yr}$ were randomized and similar to the observational data estimates, the summary rate ratio was 0.42 or a protective effect of 58\% (Padian et al. 2010). Unlike many other biomedical interventions, male circumcision is a one-time procedure for which adherence issues are limited to refraining from intercourse during healing (Padian et al. 2010). As a result of these three randomized controlled clinical trials, WHO and UNAIDS (2007) have now made strong recommendations to roll out male circumcision with all possible urgency. Most recent long-term follow-up from these studies indicate that efficacy does not decrease with time, suggesting that the long-term efficacy of the intervention outweighs any risk compensation should this phenomenon be occurring (Kong et al. 2011).

\section{MC to Prevent Male-to-Male HIV Transmission}

Observational studies of $\mathrm{MC}$ to reduce HIV transmission between MSM have shown inconsistent results perhaps because men may adopt both receptive and insertive sexual roles. In a cohort study of HIV-negative MSM, no association between circumcision status and HIV acquisition was shown (Grulich et al. 2001). It is unclear what role MC would have in bisexual men.

\section{MC to Prevent Male-to-Female HIV Transmission}

A previous observational study in HIV-discordant couples in Rakai suggested a lower rate of male-to-female HIV transmission from circumcised HIV-infected men, particularly if their viral load was below 50,000 copies per $\mathrm{mL}$ (Gray et al. 2000). A fourth prospective randomized controlled trial was conducted in discordant couples and examined HIV transmission to female partners of HIV-infected men in Rakai, Uganda (Table 4). The study was stopped prematurely for futility; however, HIV acquisition was increased in the subgroup of female partners of men who resumed sexual activity early before complete wound healing (relative risk: 2.92, 95\% CI 1.02-8.46, $P=0.06)$.

\section{Biological Explanation}

There are a number of biological studies that suggest plausible mechanisms for the protection offered by removal of the male foreskin. These are summarized in Table 6. 
L.-G. Bekker et al.

Table 5. Randomized trials of male circumcision (MC) to prevent HIV transmission

\begin{tabular}{|c|c|c|c|c|c|}
\hline Country & Funding & Study population & $\begin{array}{c}\text { Design/question/ } \\
\text { method }\end{array}$ & Outcome & Reference \\
\hline South Africa & $\begin{array}{l}\text { Agence Nationale } \\
\text { de Recherche } \\
\text { sur le Sida } \\
\text { (ANRS)/ } \\
\text { National } \\
\text { Institute for } \\
\text { Communicable } \\
\text { Diseases (South } \\
\text { Africa) }\end{array}$ & $\begin{array}{l}3274 \text { 18- to } \\
24 \text {-yr-old men } \\
\text { in a semiurban, } \\
\text { informal } \\
\text { settlement } \\
\text { called Orange } \\
\text { Farm }\end{array}$ & $\begin{array}{l}\text { Does circumcision } \\
\text { reduce male risk of } \\
\text { HIV infection by } \\
\text { female partners? } \\
\text { Study visits at months 3, } \\
\text { 12, } 21 \text { postrandomi- } \\
\text { zation; circumcision } \\
\text { performed using the } \\
\text { sleeve method. } \\
\text { Both the intervention and } \\
\text { the control group } \\
\text { received an enhanced } \\
\text { prevention package } \\
\text { beyond the local } \\
\text { standard of care. }\end{array}$ & $\begin{array}{l}\text { Stopped early. } \\
\text { MC reduced } \\
\text { the risk of } \\
\text { HIV infec- } \\
\text { tion by } \\
60 \%-61 \% \text {. }\end{array}$ & $\begin{array}{r}\text { Auvert } \\
\text { et al. } \\
2005\end{array}$ \\
\hline Uganda & $\begin{array}{l}\text { National Institutes } \\
\text { of Health/Johns } \\
\text { Hopkins } \\
\text { University, } \\
\text { Rakai Health } \\
\text { Sciences Project }\end{array}$ & $\begin{array}{l}\text { Approximately } \\
5000 \text { 15- to } \\
\text { 49-yr-old men } \\
\text { in rural Uganda } \\
\text { (Rakai District) }\end{array}$ & $\begin{array}{l}\text { Does circumcision } \\
\text { reduce male risk of } \\
\text { HIV infection by } \\
\text { female partners? } \\
\text { Four visits over } 2 \mathrm{yr} \\
\text { of follow-up; } \\
\text { circumcision } \\
\text { performed using the } \\
\text { sleeve method. } \\
\text { Both the intervention and } \\
\text { the control group } \\
\text { received an enhanced } \\
\text { prevention package } \\
\text { beyond the local } \\
\text { standard of care. }\end{array}$ & $\begin{array}{l}\text { Stopped early. } \\
\text { MC reduced } \\
\text { the risk of } \\
\text { HIV infec- } \\
\text { tion by } 48 \% \text {. }\end{array}$ & $\begin{array}{c}\text { Gray et al. } \\
2007\end{array}$ \\
\hline Kenya & $\begin{array}{l}\text { National Institutes } \\
\text { of Health and } \\
\text { Canadian } \\
\text { Institute of } \\
\text { Health } \\
\text { Research/ } \\
\text { University of } \\
\text { Nairobi, } \\
\text { University of } \\
\text { Manitoba }\end{array}$ & $\begin{array}{l}278418 \text { - to } \\
24 \text {-yr-old } \\
\text { urban } \\
\text { HIV-negative } \\
\text { men }\end{array}$ & $\begin{array}{l}\text { Does circumcision } \\
\text { reduce male risk of } \\
\text { HIV infection by } \\
\text { female partners? } \\
\text { Six study visits (months } \\
1,3,6,12,18,24) \text { over } \\
2 \text { yr; circumcision } \\
\text { performed by } \\
\text { forceps-guided } \\
\text { method. } \\
\text { Both the intervention and } \\
\text { the control group } \\
\text { received an enhanced } \\
\text { prevention package } \\
\text { beyond the local } \\
\text { standard of care. }\end{array}$ & $\begin{array}{l}\text { Stopped early. } \\
\text { MC reduced } \\
\text { the risk of } \\
\text { HIV infec- } \\
\text { tion by } 53 \% \text {. }\end{array}$ & $\begin{array}{l}\text { Bailey } \\
\text { et al. } \\
2007\end{array}$ \\
\hline
\end{tabular}


Table 5. Continued

\begin{tabular}{|c|c|c|c|c|c|}
\hline Country & Funding & Study population & $\begin{array}{l}\text { Design/question/ } \\
\text { method }\end{array}$ & Outcome & Reference \\
\hline Uganda & $\begin{array}{l}\text { Bill and Melinda } \\
\text { Gates } \\
\text { Foundation/ } \\
\text { Johns Hopkins } \\
\text { University, } \\
\text { Rakai Health } \\
\text { Sciences Project }\end{array}$ & $\begin{array}{l}200 \text { men had been } \\
\text { enrolled } \\
\text { concurrently } \\
\text { with female } \\
\text { partners and } \\
\text { had couples } \\
\text { HCT. In some, } \\
\text { the women } \\
\text { were enrolled } \\
\text { separately }\end{array}$ & $\begin{array}{l}\text { Is circumcision safe for } \\
\text { HIV-positive men? } \\
\text { How does it affect rates } \\
\text { of acquisition of STIs? } \\
\text { Does circumcision } \\
\text { reduce female risk of } \\
\text { infection by } \\
\text { HIV-positive, } \\
\text { circumcised male } \\
\text { partners? } \\
\text { Four visits over } 2 \text { yr of } \\
\text { follow-up; sleeve } \\
\text { method. }\end{array}$ & $\begin{array}{l}\text { Trial } \\
\text { suspended: } \\
\text { DSMB } \\
\text { review } \\
\text { determined } \\
\text { that the } \\
\text { study lacked } \\
\text { statistical } \\
\text { power to } \\
\text { answer its } \\
\text { study } \\
\text { question. }\end{array}$ & $\begin{array}{r}\text { Wawer } \\
\text { et al. } \\
2009\end{array}$ \\
\hline
\end{tabular}

Data from AVAC 2007 and Padian et al. 2010.

\section{Other Benefits}

The Rakai MC circumcision study conducted in 2005 also reported that men circumcised at the beginning of the study had a 50\% reduction in rates of genital ulcer disease (GUD), attributable to herpes, syphilis, and chancroid, a reduction in acquisition of genital herpes (27\%), and a $30 \%-35 \%$ reduction in rates of human papillomavirus (HPV), including the types that cause cancer. Benefits also extended to the female partners of the circumcised men: a 50\% reduction in rates of GUD, as well as a dramatic reduction in trichomoniasis, HPV infection, and bacterial vaginosis (Bailey et al. 2001;
Weis et al. 2006). HIV-infected men may also experience less GUD (Schneider et al. 2010).

\section{Current Implementation Programs}

Although the efficacy of MC on reducing individual risk is clear, the population-level effectiveness of this procedure in reducing HIV transmission will depend heavily on the acceptability of male circumcision programs in specific populations (Westercamp and Bailey 2007). Data on its acceptability among adults show this is likely to be highly context-specific and influenced by local cultural norms and practices (Eaton and Kalichman 2009).

Table 6. Some biological reasons for the protection against HIV acquisition in men undergoing male circumcision

\begin{tabular}{|c|c|}
\hline Explanation & Reference(s) \\
\hline $\begin{array}{l}\text { 1. The inner mucosal surface of the human foreskin, exposed on erection, } \\
\text { has nine times higher density of HIV target cells (Langerhans' cells, } \\
\mathrm{CD} 4^{+} \mathrm{T} \text { cells, and macrophages) than does cervical tissue. }\end{array}$ & Patterson et al. 2002 \\
\hline $\begin{array}{l}\text { 2. The foreskin's inner surface lacks the protective layer of squamous } \\
\text { epithelial cell HIV target cells found on the outer surface and the glans. }\end{array}$ & McCoombe and Short 2006 \\
\hline $\begin{array}{l}\text { 3. In explant culture, several times more HIV is taken up by Langerhans' } \\
\text { cells and } \mathrm{CD}^{+} \mathrm{T} \text { cells in foreskin than in cervical tissue. }\end{array}$ & Patterson et al. 2002 \\
\hline $\begin{array}{l}\text { 4. A foreskin is associated with increased incidence of ulcerative sexually } \\
\text { transmitted infections; the number of HIV target cells in the prepuce is } \\
\text { increased in the setting of recent STIs. }\end{array}$ & $\begin{array}{l}\text { Weis et al. 2006; Bailey et al. 2001; } \\
\text { Donoval et al. } 2006\end{array}$ \\
\hline 5. Susceptibility of the foreskin to abrasions. & \\
\hline
\end{tabular}


L.-G. Bekker et al.

\section{STI INTERVENTIONS}

Longitudinal studies have shown substantial relative risks for HIV infection associated with various STIs with syphilis, chancroid, and genital herpes having larger effects on susceptibility than gonorrhea, chlamydia, and trichomonas (Stamm et al. 1988; Rottingen et al. 2001). These ulcerative diseases appear to create an entry point for the virus by disrupting the genital epithelial barrier leading to a greater susceptibility (Ghys et al. 1997). In addition, studies have shown that HIV viral shedding in the genital tract is substantially increased with a sexually transmitted coinfection, and this replication is reduced after treatment of the STI (Eron et al. 1996).

As a result, efforts to ensure prompt diagnosis and treatment of STIs along with behavioral risk reduction have been part of HIV prevention programming since the 1980s. In 1989, Pepin and colleagues suggested that the interaction of HIV and STIs may present an opportunity for intervention (Pepin et al. 1989). Empirical evidence for this intervention has included uncontrolled intervention studies among sex workers and community-based RCTs in general populations (Laga et al. 1994).

\section{Clinical Trials of STI Treatment}

Eight of the nine RCTs of STI treatment for HIV prevention showed no effect, although one additional study found a significant reduction on HIV incidence in a subgroup of men who attended program meetings (Table 7) (Gregson et al. 2007). Four community-randomized trials have been conducted to assess the effect on HIV transmission and HIV acquisition through reduction of the incidence of the most common curable STIs. Of all four study outcomes, only the Mwanza trial reported significant reduction (38\%) in HIV incidence. Many possible reasons for this discrepancy have been cited but most compelling are the differences between the stage of the epidemic in Uganda and Tanzania when the studies were performed. The epidemic in Uganda was more established (HIV prevalence $16 \%$ and stable) with lower risk behavior and lower rates of curable STIs. In contrast, the HIV prevalence in Mwanza was 4\% and rising with much greater rates of STIs (Grosskurth et al. 2000).

These data would suggest that STI treatment interventions can have an impact where treatable STIs are prevalent and where HIV incidence is very high in the general populations. However, even if the HIV epidemic has matured in the general adult population, adolescents as they sexually debut may initially have low HIV prevalence and constitute a population where STI control may be very important. It is still recommended that STI treatment should be an essential component of HIV control programs in communities in which the burden of STIs is substantial (Grosskurth et al. 2000; Hayes et al. 2010).

\section{Herpes Simplex 2 and HIV Transmission}

In SSA, HSV-2 infections have a two- to threefold increased effect on HIV acquisition in the general population (Freeman et al. 2006). Initial proof of concept, randomized trials of suppressive treatment with valiciclovir reported reduced HIV shedding in genital secretions of coinfected individuals, suggesting potential for reduced HIV transmission risk (Nagot et al. 2007; Zuckerman et al. 2007). Subsequently, in three RCTs, antivirals for herpes simplex virus (HSV) suppression were insufficiently potent to alleviate persistent genital inflammation in HIV-negative HSV2-positive persons, and the reduction in HIV levels in HIV-positive persons was insufficient to reduce HIV transmission (Table 7) (Hayes et al. 2010).

\section{HIV PREVENTION AMONG INJECTING DRUG USERS}

HIV prevention for people who inject drugs (commonly referred to as injecting drug users, or IDUs) presents a difficult paradox. There is abundant evidence for the efficacy of a number of interventions for this population, and clear and compelling data has emerged on the efficacy of combinations of these interventions in 
Table 7. The randomized trials of treatment of STIs to reduce HIV transmission

\begin{tabular}{|c|c|c|c|c|}
\hline Intervention & Country/region & $\begin{array}{l}\text { Target population } \\
\text { and annual HIV } \\
\text { incidence (ppy) }\end{array}$ & Efficacy/outcome & Reference \\
\hline $\begin{array}{l}\text { Individual syndromic STI } \\
\text { treatment to reduce HIV } \\
\text { incidence }(\mathrm{CRCT})\end{array}$ & $\begin{array}{l}\text { Mwanza, } \\
\text { Tanzania }\end{array}$ & $\begin{array}{l}\text { General } \\
\text { population; } \\
0.9 \%\end{array}$ & $\begin{array}{l}38 \% \text { reduction in } \\
\text { HIV incidence }\end{array}$ & $\begin{array}{l}\text { Grosskurth } \\
\text { et al. } 2000\end{array}$ \\
\hline $\begin{array}{l}\text { STI therapy }{ }^{\mathrm{b}} \text { to reduce HIV } \\
\text { incidence (everyone treated } \\
\text { every } 10 \mathrm{mo})(\mathrm{CRCT})\end{array}$ & Rakai, Uganda & $\begin{array}{l}\text { General } \\
\text { population; } 1.5 \\
\text { ppy }\end{array}$ & Nil & $\begin{array}{l}\text { Wawer et al. } \\
2009\end{array}$ \\
\hline $\begin{array}{l}\text { Individual RCT of intensive, } \\
\text { microscopy-assisted } \mathrm{STI}^{\mathrm{a}} \\
\text { screening and treatment to } \\
\text { reduce HIV incidence }\end{array}$ & & FSW; 7.6 ppy & Nil & $\begin{array}{l}\text { Ghys et al. } \\
1997\end{array}$ \\
\hline $\begin{array}{l}\text { Individual syndromic } \mathrm{STI}^{\mathrm{b}} \text { to } \\
\text { reduce } \mathrm{HIV} \text { incidence (CRCT) }\end{array}$ & $\begin{array}{l}\text { Masaka, (rural) } \\
\text { Uganda }\end{array}$ & $\begin{array}{l}\text { General } \\
\text { population; } \\
0.8 \text { ppy }\end{array}$ & Nil & $\begin{array}{l}\text { Kamali et al. } \\
2003\end{array}$ \\
\hline $\begin{array}{l}\text { Treatable STI }{ }^{\mathrm{a}} \text { periodic } \\
\text { presumptive therapy } \\
\text { Individual RCT }\end{array}$ & Kenya & FSW; 3.2 ppy & Nil & $\begin{array}{c}\text { Kaul et al. } \\
2004\end{array}$ \\
\hline $\begin{array}{l}\text { Individual syndromic STI } \\
\text { treatment }^{\mathrm{a}} \text { to reduce HIV } \\
\text { incidence }(\mathrm{CRCT})\end{array}$ & $\begin{array}{l}\text { Manicaland, } \\
\text { Zimbabwe }\end{array}$ & $\begin{array}{l}\text { General } \\
\text { population; } 1.5 \\
\text { ppy }\end{array}$ & $\begin{array}{l}\text { Nil; subgroup of } \\
\text { men who } \\
\text { attended program } \\
\text { meetings (IRR } \\
0.48 ; p=0.04)\end{array}$ & $\begin{array}{l}\text { Gregson et al. } \\
2007\end{array}$ \\
\hline HSV-2 suppression ${ }^{c}$ & Tanzania & $\begin{array}{l}\text { HSV-2-positive } \\
\text { women; } 4.1 \text { ppy }\end{array}$ & Nil & $\begin{array}{l}\text { Watson- } \\
\text { Jones et al. } \\
2008\end{array}$ \\
\hline HSV-2 suppression ${ }^{c}$ & $\begin{array}{l}\text { Africa; Peru } \\
\text { and United } \\
\text { States }\end{array}$ & $\begin{array}{l}\text { WSM; MSM HSV2 } \\
\text { seropositive; } 3.3 \\
\text { ppy }\end{array}$ & $\begin{array}{l}\text { Nil (some benefit in } \\
\text { subset of women } \\
\text { who took }>90 \% \\
\text { of doses) }\end{array}$ & $\begin{array}{l}\text { Celum et al. } \\
2008\end{array}$ \\
\hline HSV-2 suppression ${ }^{c}$ & Africa & $\begin{array}{l}\mathrm{HIV} / \mathrm{HSV}-2 \\
\text { positive; } 2.7 \text { ppy }\end{array}$ & Nil & $\begin{array}{l}\text { Celum et al. } \\
2010\end{array}$ \\
\hline
\end{tabular}

ppy, per hundred person years or annual percentage; CRCT, community randomized control trial; FSW, female sex workers; HSV-2, herpes simplex virus 2; IRR, incidence rate ratio; WSM; women who have sex with men.

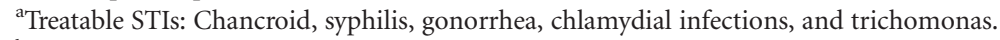

${ }^{\mathrm{b}}$ Single-dose oral antibiotic.

${ }^{\mathrm{c}}$ Acyclovir treatment.

achieving control of HIV spread via this route (Degenhardt et al. 2010). Yet IDU remain the least served of any risk group globally for prevention, treatment, and care (Wolfe et al. 2010). Epidemics driven by IDU risks and by risk-enhancing structural and policy environments continue to expand in 2010 (Beyrer et al. 2010). These policy failures include punitive and repressive drug laws, criminalization of drug dependency and possession, and the continued resistance to the provision of evidence-based drug treatment, including methadone maintenance therapy in many states and regions (Strathdee et al. 2010).

HIV spread among IDUs has been driven largely, but not exclusively, by injecting use of heroin. Cocaine, methamphetamine, and combinations are also important substances associated with injecting risks. Heroin predominates in Eastern Europe and Central Asia, North, South, and Southeast Asia, and Western Europe, 
L.-G. Bekker et al.

encompassing the major populations at risk for HIV through injecting (Mathers et al. 2008). The most recent global estimate, from the reference group to the United Nations on HIV and injecting drug use was that some 15.9 million persons (range from 11.0 to 21.2 million) worldwide were IDU in 2007 (Beyrer 2010).

\section{Evidence for Efficacy}

The literature on HIV prevention for this population is large and growing (Degenhardt et al. 2010). The most compelling recent data suggest, as with prevention of sexual transmission, that no single intervention alone can reduce HIV risks enough to control injecting-driven epidemics. Encouragingly, however, recent modeling studies show that combination approaches to HIV prevention for this population can be synergistic in effect and have real impact on HIV risks at individual, couple, network, and population levels of spread (Degenhardt et al. 2010).

The components of effective prevention services for IDU include individual and higherlevel interventions (Table 8). An essential component is access to safe injecting equipment. Because the primary risk for HIV acquisition and transmission among drug users is the reuse of contaminated injecting equipment, multiple approaches to reducing equipment reuse, termed needle and syringe exchange programs (NSP), have been developed. The provision of equipment for people who inject has proven politically challenging in many contexts, because this has been seen (based on no empirical evidence) as "encouraging" injecting. Indeed, the U.S. federal ban on funding for such programs, lifted in 2010 by the Obama administration, was based on this unsound premise (Beyrer et al. 2010). A recent global review and modeling exercise of the evidence for efficacy suggests that with high coverage, NSP can reduce HIV incidence at population levels by $20 \%$ over 5 years, but the reduction is too modest to control HIV spread (Degenhardt et al. 2010).

A second critical component of HIV prevention for IDU is drug treatment. The first agent shown to have efficacy in reduction of HIV transmission among drug users was methadone (Metzger et al. 1999). Because methadone is an oral administered liquid and an opiate agonist, opioid-dependent patients can be maintained on the agent and reduce dramatically their injecting drug use. This simple "substitution" therapy, as it has come to be known, was shown by Metzger and colleagues (1999) to markedly reduce HIV infection rates among IDU in Philadelphia in the 1990s. Newer agents are also now available, but there have been significant obstacles to the

Table 8. Structural interventions associated with prevention in injection drug use

\begin{tabular}{|c|c|c|c|c|}
\hline Level & Physical environment & Social environment & Economic environment & Policy environment \\
\hline Micro & $\begin{array}{l}\text { Unsafe drug use, } \\
\text { injecting, and sex } \\
\text { work locations } \\
\text { Injecting in public } \\
\text { places } \\
\text { Detention centers }\end{array}$ & $\begin{array}{l}\text { Social and peer group risk } \\
\text { norms } \\
\text { Policing and crackdowns } \\
\text { Lack of health and welfare } \\
\text { services }\end{array}$ & $\begin{array}{l}\text { Cost of living and } \\
\text { health services } \\
\text { Cost of prevention } \\
\text { services } \\
\text { Lack of income- } \\
\text { generation } \\
\text { opportunities }\end{array}$ & $\begin{array}{l}\text { Access to clean needles } \\
\text { and syringes } \\
\text { Policy and programs for } \\
\text { distribution } \\
\text { Housing access }\end{array}$ \\
\hline Macro & $\begin{array}{l}\text { Drug traffic and } \\
\text { distribution routes } \\
\text { Population mobility }\end{array}$ & $\begin{array}{l}\text { Sex inequalities and risk } \\
\text { Stigmatization and } \\
\text { marginalization of IDU } \\
\text { Inadequate public } \\
\text { advocacy }\end{array}$ & $\begin{array}{l}\text { Reduced public } \\
\text { spending } \\
\text { Increase in informal } \\
\text { income generation } \\
\text { Economic uncertainty }\end{array}$ & $\begin{array}{l}\text { Laws governing human } \\
\text { rights } \\
\text { Laws governing drug } \\
\text { possession } \\
\text { Public health policy and } \\
\text { harm-reduction } \\
\text { services }\end{array}$ \\
\hline
\end{tabular}

Data adapted from Degenhardt et al. 2010. 
widespread use of these agents. Methadone was strongly opposed by the Soviet Union when it was first introduced, and opioid substitution therapy (OST) remains illegal in Russia (Beyrer et al. 2010).

Although NSP and OST in combination can reduce HIV risks, recent modeling work by $\mathrm{Hal}$ lett et al., reported by Degenhardt et al. (2010), showed that a third element is essential for individuals and for epidemics: access to antiretroviral therapies (ARVs). ARV access for IDUs alone had roughly the same impact on HIV incidence as the combination of OST and NSP, and was significantly higher when ARVs were available to HIV-infected IDU at higher ( <350 CD4s) levels. They found a dramatic synergistic impact of provision of NSP, OST, and ARV on reducing HIV incidence over time, with a 39\% reduction in population levels of HIV infection over 5 years with the combination approach (Degenhardt et al. 2010). This model assumed quite modest levels of efficacy for each component at the individual level (60\% for OST, $40 \%$ for NSP, and $90 \%$ for ARVs when initiated at the higher CD4 level) (Degenhardt et al. 2010).

\section{Challenges and Opportunities for Implementation}

Although it is tremendously encouraging to show the synergistic effects of combined preventive interventions on HIV incidence at population levels among IDUs, the realities of access to care for this population are sobering. Wolfe et al. reviewed access to care for IDUs in selected high-burden countries and found that among all populations at risk for HIV infection, IDUs remained the least served (Wolfe et al. 2010). An even more telling finding was that in China and Vietnam, the number of drug users in detention is three times and 33 times higher, respectively, than those in treatment. Incarceration is not an evidence-based approach to HIV prevention, but rather a welldescribed risk for HIV infection among drug users (Beyrer et al. 2010).

Strathdee et al. used the risk-environment framework to investigate another aspect of IDU risks that poses real challenges-the social, policy, and legal environments that can reduce, or drive, HIV risks (Strathdee et al. 2010). They found that structural aspects of risk environments had substantial impacts on HIV risks and disease spread. As IDU risks emerge in new settings, as was happening in East and South Africa in 2010, these challenges are likely to continue to undermine our responses (Beyrer et al. 2010).

\section{STRUCTURAL APPROACHES TO HIV PREVENTION}

Structural factors in HIV epidemics are defined as "physical, social, political, cultural, organizational, community, economic, legal, or policy aspects of the environment that facilitate or obstruct efforts to avoid HIV infection" (Gupta et al. 2008). Structural interventions are programs or policies that seek to address these factors and prevent HIV acquisition through altering the context and mechanisms by which the behavior occurs rather than targeting the behavior itself (Gupta et al. 2008).

\section{Evidence Linking Structural Factors to HIV}

The literature cites both indirect associations, such as increased HIV vulnerability among orphaned or homeless children (Hallman 2005), and more direct associations, such as studies on migration linking South African mine workers and their high-risk work conditions plus separation from family to unprotected sex with prostitutes (Lurie et al. 2003). Associations, however, are not always clear-cut: Although poverty has been linked to HIV vulnerability, in a study of household wealth and HIV prevalence in population-based surveys in SSA, HIV prevalence was highest in the wealthier sector of the population in six of the eight surveys studied (Sumartojo et al. 2000; Hallman 2005).

\section{Examples of Structural Approaches in HIV Prevention}

Structural approaches may be single policies or programs (revoking a discriminatory law, e.g., the South African sodomy law in 1994) 
L.-G. Bekker et al.

or transformational processes (community mobilization for MC in KwaZulu Natal following King Goodwill's pronouncement that Zulu men should be circumcised). Their common purpose is to change the social, economic, political, or environmental factors that determine HIV risk and vulnerability in specific settings (Gupta et al. 2008). The policy and legal shifts that enabled NSP and OST to operate for IDUs is an example of a successful structural intervention (Drucker et al. 1998).

Within the social framework, school retention has been linked to a lower HIV acquisition risk. This effect may be caused by reducing child prostitution, child labor, and antisocial behavior as well as opportunities for HIV and sex education (Hallman 2006). A higher level of education is associated with safer sexual practices and a later sexual debut (Prata et al. 2005), yet school fees are a major barrier to school attendance in the developing world.

One of the ways economic frameworks create a risk environment for HIV is through women's financial dependency on men and the lack of opportunities for both sexes in the developing world. Microcredit programs, for example, may reduce women's HIV vulnerability by strengthening their economic options (Hargreaves et al. 2002; Hall 2006).

\section{Designing Structural Interventions and Their Evaluation}

This effort requires an analysis of social, political, economic, and environmental factors in a given setting that increase risk or vulnerability. Different factors may have more than one causal pathway from the structural factor to the behavior(s) that need to change to reduce risk (Over 1998).

A review of 24 IDU harm reduction programs in 1989 found prevention efficacy for such programs without associated adverse events. Further structural interventions to reduce some legal limitations, increase community and social mobilization, and upscale such programs holds great potential for reducing HIV vulnerabilities among IDUs (Table 7) (Degenhardt et al. 2010). Some successful structural interventions have occurred at the country or district level. The Mbeya region in Tanzania is one of the most affected regions in the country but reported a $7 \%$ decrease in HIV prevalence over a few years. The intervention included a single regional HIV plan with political support, regional AIDS coordination, and involvement of business and nongovernmental organizations (NGOs) (Vogel 2007).

It is possible that individuals will find it difficult to change their behavior in relation to HIV risk until they have a stronger social, political, economic, and environmental framework in which to live their lives. As a result, structural approaches that are context-specific and evidence-based should be a part of an overall HIV prevention package that includes behavioral and biomedical approaches (Gupta et al. 2008).

\section{CONCLUSION}

The aim of the Sixth Millennium Development Goal is to halt, and reverse, the spread of HIV by 2015. This article describes an impressive array of evidence-based devices (condoms, harm reduction, $\mathrm{MC}$ ) that can be implemented along with information, skills, and services. Concerted HIV prevention efforts from countries as diverse as Thailand, Australia, and Senegal have resulted in maintenance of low seroprevalence rates (Winkelstein et al. 1987; Kippax et al. 2003). Other studies conducted in high-risk populations have shown that HIV prevention can work, even in the most challenging settings. Yet, despite this, UNAIDS tells us that only $60 \%$ of sex workers, $46 \%$ of injection drug users, and $40 \%$ of MSM were reached with HIV prevention programs in 2008 (UNAIDS 2008). The positive results of biomedical interventions in 2010 and those expected over the next several years give promise that a number of other interventions can be added to the menu. The era is one of HARP-targeted, strategic, and creative combinations of behavioral, biomedical, and structural interventions. These programs will require universal access, widescale implementation, careful monitoring, and evaluation, financial, and technical resources 
and robust commitment at regional and country levels (Coates et al. 2008; Merson et al. 2008). We may then begin to see a substantial impact on the spread of HIV globally.

\section{REFERENCES}

Allen S, Meinzen-Derr J, Kautzman M, Zulu I, Trask S. 2003. Sexual behavior of HIV discordant couples after HIV counseling and testing. Aids 17: 733-740.

Auerbach J, Coates T. 2000. HIV prevention research: Accomplishments and challenges for the third decade of AIDS. Am J Public Health 90: 1029-1032.

Auvert B, Taljaard D, Lagarde E, Sobngwi-Tambekou J, Sitta R, Puren A. 2005. Randomized, controlled intervention trial of male circumcision for reduction of HIV infection risk: The ANRS 1265 trial. PLoS Med 2: e298. doi: 10.1371/journal.pmed.0020298.

AVAC. 2007. A new way to protect against HIV? Understanding the results of male circumcision studies for HIV prevention. AIDS Vaccine Advocacy Coalition's Anticipating and Understanding Results series, September 2007, updated ed.

Baggaley RF, Garnett GP, Ferguson NM. 2006. Modelling the impact of antiretroviral use in resource-poor settings. PLoS Med 3: e124. doi: 10.1371/journal.pmed. 0030124.

Bailey RC, Plummer FA, Moses S. 2001. Male circumcision and HIV prevention: Current knowledge and future research directions. Lancet Infect Dis 1: 223-231.

Bailey RC, Moses S, Parker CB, Agot K, Maclean I, Krieger JN, Williams CF, Campbell RT, Ndinya-Achola JO. 2007. Male circumcision for HIV prevention in young men in Kisumu, Kenya: A randomised controlled trial. Lancet 369: 643-656.

Barouche D. 2008. Challenges in the development of an HIV-1 vaccine. Nature 455: 613-617.

Bateganya MH, Abdulwadud OA, Kiene SM. 2007. Homebased HIV voluntary counseling and testing in developing countries. Cochrane DB Syst Rev 4: CD006493.

Beyrer C, Malinowska-Sempruch K, Kamarulzaman A, Kazatchkine M, Sidibe M, Strathdee SA. 2010. Time to act: A call for comprehensive responses to HIV in people who use drugs. Lancet 376: 551-563.

Bongaarts J, Reining P, Way P, Conant F. 1989. The relationship between male circumcision and HIV infection in African populations. AIDS 3: 373-377.

Buchbinder SP, Vittinghoff E, Heagerty PJ, Celum CL, Seage GR III, Judson FN, McKirnan D, Mayer KH, Koblin BA. 2005. Sexual risk, nitrite inhalant use, and lack of circumcision associated with HIV seroconversion in men who have sex with men in the United States. J Acquir Immune Defic Syndr 39: 82-89.

Caldwell JC, Caldwell P. 1996. The African AIDS epidemic. Sci Am 274: 62-63, 66-68.

Castilla J, Del Romero J, Hernando V, Marincovich B, Garcia S, Rodriguez C. 2005. Effectiveness of highly active antiretroviral therapy in reducing heterosexual transmission of HIV. J Acquir Immune Defic Syndr 40: 96-101.
Celum C, Wald A, Hughes J, Sanchez J, Reid S, Delany-Moretlwe S, Cowan F, Casapia M, Ortiz A, Fuchs J, et al. 2008. Effect of aciclovir on HIV-1 acquisition in herpes simplex virus 2 seropositive women and men who have sex with men: A randomised, double-blind, placebo-controlled trial. Lancet 371: 2109-2119.

Celum C, Wald A, Lingappa JR, Magaret AS, Wang RS, Mugo N, Mujugira A, Baeten JM, Mullins JI, Hughes JP, et al. 2010. Acyclovir and transmission of HIV-1 from persons infected with HIV-1 and HSV-2. N Engl J Med 362: 427-439.

Coates T, Richter L, Caceres C. 2008. Behavioural strategies to reduce HIV transmission: How to make them work better. Lancet 372: 669-684.

Coffey PS, Kilbourne-Brook M, Austin G, Seamans Y, Cohen J. 2006. Short-term acceptability of the PATH woman's condom among couples at three sites. Contraception 73: $588-593$.

Cohen J. 2005. HIV/AIDS: Prevention cocktails: Combining tools to stop HIV's spread. Science 309: 1002-1005.

Cohen M, Hoffman I, Royce R, Kazembe P, Dyer JR, Costello Daly C, Zimba D, Vernazza PL, Maida M, et al. 1997. Reduction of concentration of HIV-1 in semen after treatment of urethritis: Implications for prevention of sexual transmission of HIV-1. Lancet 349: 1868-1873.

Cohen MS, Chen YQ, McCauley M, Gamble T, Hosseinipour MC, Kumarasamy N, Hakim JG, Kumwenda J, Grinsztejn B, Pilotto JH, et al. 2011. Prevention of HIV-1 infection with early antiretroviral therapy. $N$ Engl J Med 365: 493-505.

Cohen MS, Gay C, Kashuba ADM, Blower S, Paxton L. 2007. Narrative Review: Antiretroviral therapy for prevention of the sexual transmission of HIV-1. Ann Intern Med 146: $591-601$.

Collins C, Coates TJ, Curran J. 2008. Moving beyond the alphabet soup of HIV prevention. AIDS 22 (Suppl. 2): S5-S8.

Corbett EL, Makamure B, Cheung YB, Dauya E, Matambo R, Bandason T, Munyati SS, Mason PR, Butterworth AE, Hayes RJ. 2007. HIV incidence during a clusterrandomized trial of two strategies providing voluntary counselling and testing at the workplace, Zimbabwe. AIDS 21: 483-489.

Cowan FM, Pascoe SJS, Langhaug LF, Dirawo J, Mavhu W, Chidiya S, Jaffar S, Mbizuo M, Stephenson JM, Johnson AM, et al. 2009. The Regai Dzive Shiri Project: The results of a cluster randomized trial of a multi-component HIV prevention intervention for young people in rural Zimbabwe. 18th International Society for Sexually Transmitted Disease Research, London.

Cu-Uvin S, Caliendo AM, Reinert S, Chang A, JulianoRemollino C, Flanigan TP, Mayer KH, Carpenter CC. 2000. Effect of highly active antiretroviral therapy on cervicovaginal HIV-1 RNA. AIDS 14: 415-421.

De Cock KM, Crowley SP, Lo Y.-R, Granich RM, Williams BG. 2009. Preventing HIV transmission with antiretrovirals. B World Health Organ 87: 488-488A.

Degenhardt L, Mathers B, Vickerman P, Rhodes T, Latkin C, Hickman M. 2010. Prevention for people who inject drugs: Why individual, structural, and combination approaches are required. Lancet 376: 285-301. 
L.-G. Bekker et al.

Denison JA, O’Reilly KR, Schmid GP, Kennedy CE, Sweat MD. 2008. HIV voluntary counseling and testing and behavioral risk reduction in developing countries: A meta-analysis, 1990-2005. Aids Behav 12: 363-373.

Donoval BA, Landay AL, Moses S, Agot K, Ndinya-Achola JO, Nyagaya EA, MacLean I, Bailey RC. 2006. HIV-1 target cells in foreskins of African men with varying histories of sexually transmitted infections. Am J Clin Pathol 125: 386-391.

Drew WL, Blair M, Miner RC, Conant M. 1990. Evaluation of the virus permeability of a new condom for women. Sex Transm Dis 17: 110-112.

Drucker E, Lurie P, Wodak A, Alcabes P. 1998. Measuring harm reduction: The effects of needle and syringe exchange programs and methadone maintenance on the ecology of HIV. AIDS 12: S217-S230.

Dunkle KL, Stephenson R, Karita E, Chomba E, Kayitenkore K, Vwalika C, Greenberg L, Allen S. 2008. New heterosexually transmitted HIV infections in married or cohabiting couples in urban Zambia and Rwanda: An analysis of survey and clinical data. Lancet 371: 2183-2191.

Eaton L, Kalichman SC. Behavioral aspects of male circumcision for the prevention of HIV infection. Curr HIV/ AIDS Rep 6: 187-193.

Eron JJ Jr, Gilliam B, Fiscus S, Dyer J, Cohen MS. 1996. HIV1 shedding and chlamydial urethritis. JAMA 275: 36.

Fang CT, Hsu HM, Twu SJ, Chen MY, Chang YY, Hwang JS, Wang JD, Chuang CY. 2004. Decreased HIV transmission after a policy of providing free access to highly active antiretroviral therapy in Taiwan. J Infect Dis 190: 879-885.

Fideli US, Allen SA, Musonda R, Trask S, Hahn BH, Weiss H, Mulenga J, Kasolo F, Vermund SH, Aldrovandi GM. 2001. Virologic and immunologic determinants of heterosexual transmission of human immunodeficiency virus type 1 in Africa. AIDS Res Hum Retrov 17: 901-910.

Fink AJ. 1986. In defense of circumcision. Pediatrics 77: 265-267.

Foss AM, Hossain M, Vickerman PT, Watts CH. 2007. A systematic review of published evidence on intervention impact on condom use in sub-Saharan Africa and Asia. Sex Transm Infect 83: 510-516.

Freeman EE, Weiss HA, Glynn JR, Cross PL, Whitworth JA, Hayes RJ. 2006. Herpes simplex virus 2 infection increases HIV acquisition in men and women: Systematic review and meta-analysis of longitudinal studies. AIDS 20: $73-83$.

French PP, Latka M, Gollub EL, Rogers C, Hoover DR, Stein ZA. 2003. Use-effectiveness of the female versus male condom in preventing sexually transmitted disease in women. Sex Transm Dis 30: 433-439.

Galvao LW, Oliveira LC, Diaz J, Kime D-J, Marchif N, van Damg J, Castilhoc RF, Chenh M, Maurizio M. 2005. Effectiveness of female and male condoms in preventing exposure to semen during vaginal intercourse: A randomized trial. Contraception 71: 130-136.

Ghys P, Fransen K, Diallo O, Ettiègne-Traoré V, Coulibaly IM, Yeboué KM, Kalish ML, Maurice C, Whitaker JP, Greenberg AE, et al. 1997. The associations between cervicovaginal HIV shedding, sexually transmitted diseases, and immunosuppression in sex workers in Abidjan, Cote d'Ivoire. AIDS 11: F85-F93.
Golden M. 2006. HIV serosorting among men who have sex with men: Implications for prevention. 13th Conference on Retroviruses and Opportunistic Infections, Denver, CO, abstract 163.

Granich R, Gilks C, Dye C, DeCock K, Williams B. 2009. Universal voluntary HIV testing with immediate antiretroviral therapy as a strategy for elimination of HIV transmission: A mathematical model. Lancet 373: 48-57.

Granich R, Crowley S, Vitoria M, Smyth C, Kahn JG, Bennett R, Lo YR, Souteyrand Y, Williams B. 2010. Highly active antiretroviral treatment for the prevention of HIV transmission. J Int AIDS Soc 13: 1.

Grant RM, Lama JR, Anderson PL, McMahan V, Liu AY, Vargas L, Goicochea P, Casapía M, Guanira-Carranza JV, Ramirez-Cardich ME, et al. 2010. Preexposure chemoprophylaxis for HIV prevention in men who have sex with men. N Engl J Med 363: 2587-2599.

Gray RH, Kiwanuka N, Quinn TC, Sewankambo NK, Serwadda D, Mangen FW, Lutalo T, Nalugoda F, Kelly R, Meehan M, et al. 2000. Male circumcision and HIV acquisition and transmission: Cohort studies in Rakai, Uganda. Rakai Project Team. AIDS 14: 2371-2381.

Gray RH, Wawer MJ, Brookmeyer R, Sewankambo NK, Serwadda D, Wabwire-Mangen F, Lutalo T, Li X, vanCott T, Quinn TC, Rakai Project Team, et al. 2001. Probability of HIV-1 transmission per coital act in monogamous, heterosexual, HIV-1-discordant couples in Rakai, Uganda. Lancet 357: 1149-1153.

Gray RH, Kigozi G, Serwadda D, Makumbi F, Watya S, Nalugoda F, Kiwanuka N, Moulton LH, Chaudhary MA, Chen MZ, et al. 2007. Male circumcision for HIV prevention in men in Rakai, Uganda: A randomised trial. Lancet 369: 657-666.

Gregson S, Adamson S, Papaya S, Mundondo J, Nyamukapa CA, Mason PR, Garnett GP, Chandiwana SK, Foster G, Anderson RM. 2007. Impact and process evaluation of integrated community and clinic-based HIV-1 control A cluster-randomised trial in eastern Zimbabwe. PLoS Med 4: e102. doi: 10.1371/journal.pmed.0040102.

Grosskurth H, Gray R, Hayes R, Mabey D, Wawer M. 2000. Control of sexually transmitted diseases for HIV-1 prevention: Understanding the implications of the Mwanza and Rakai trials. Lance 355: 1981-1987.

Grulich AE, Hendry O, Clark E, Kippax S, Kaldor JM. 2001. Circumcision and male-to-male sexual transmission of HIV. AIDS 15: 1188-1189.

Gupta GR, Parkhurst J, Ogden J, Aggleton P, Mahal A. 2008. Structural approaches to HIV prevention. Lancet 372: 765-775.

Hall J. 2006. Microfinance brief: Tap and reposition youth (TRY) program. Population Council, New York.

Hallman K. 2005. Gendered socioeconomic conditions and HIV risk behaviours among young people in South Africa. Afr J AIDS Res 4: 37-50.

Hallman K. 2006. HIV vulnerability of non-enrolled and urban poor girls in Kwa-Zulu Natal, South Africa. Population Council, New York.

Harding R, Golombok S, Sheldon J. 2000. A clinical trial of a thicker versus a standard condom for gay men. 13th International AIDS Conference, Durban. Abstract WePpC1395. 
Hargreaves J, Atsbeha T, Gear J, Kim J, Mzamani Makhubele B, Mashaba K, Morison L, Motsei M, Peters C, Porter J, et al. 2002. Social interventions for HIV/AIDS: Intervention with microfinance for AIDS gender equity. IMAGE Study Evaluation Monograph. RADAR and Small Enterprise Foundation Publishers.

Hayes R, Watson-Jones D, Celum C, van de Wijgert J, Wasserheit J. 2010. Treatment of sexually transmitted infections for HIV prevention: End of the road or new beginning? AIDS 24: S15-S26.

Helleringer S, Kohler HP, Frimpong JA, Mkandawire J. 2009. Increasing uptake of HIV testing and counseling among the poorest in sub-Saharan countries through homebased service provision. J Acquir Immune Defic Syndr 51: 185-193.

Jewkes R, Nduna M, Levin J, Jama N, Dunkle K, Puren A, Duvvury N. 2008. Impact of stepping stones on incidence of HIV and HSV-2 and sexual behaviour in rural South Africa: Cluster randomised controlled trial. BMJ 337: a506. doi: 10.1136/bmj.a506.

Jürgens R, Csete J, Amon J, Baral S, Beyrer C. 2010. People who use drugs, HIV and human rights. Lancet 376: 355-366.

Kamali A, Quigley M, Nakiyingi J, Kinsman J, KengeyaKayondo J, Gopal R, Ojwiya A, Hughes P, Carpenter LM, Whitworth J, et al. 2003. Syndromic management of sexually-transmitted infections and behaviour change interventions on transmission of HIV-1 in rural Uganda: A community randomised trial. Lancet 361: 645-652.

Karim QA, Karim SSA, Frohlich JA, Grobler AC, Baxter C, Mansoor LE, Kharsany AB, Sibeko S Mlisana KP, Omar Z, et al. 2010. Effectiveness and safety of tenofovir gel, an antiretroviral microbicide, for the prevention of HIV infection in women. Science 329: 1168-1174.

Katz MH, Schwarcz SK, Kellogg TA, Klausner JD, Dilley JW, Gibson S, McFarland W, et al. 2002. Impact of highly active antiretroviral treatment on HIV seroincidence among men who have sex with men: San Francisco. Am J Public Health 92: 388-394.

Kaul R, Kimani J, Nagelkerke NJ, Fonck K, Ngugi EN, Keli F, MacDonald KS, Maclean IW, Bwayo JJ, Temmerman M, et al. 2004. Monthly antiobiotic chemoprophylaxis and incidence of sexually transmitted infections and HIV-1 infection in Kenyan sex workers: A randomized controlled study. JAMA 291: 2555-2562.

Kerrigan D, Moreno L, Rosario S, Gomez B, Jerez H, Barrington C, Weiss E, Sweat M. 2006. Environmentalstructural interventions to reduce HIV/STI risk among female sex workers in the Dominican Republic. Am J Public Health 96: 120-125.

Khumalo-Sakutukwa G, Morin SF, Fritz K, Charlebois ED, van Rooyen $\mathrm{H}$, Chingono A, Modiba P, Mrumbi K, Visrutaratna S, Singh B, et al. 2008. Project accept (HPTN 043): A community-based intervention to reduce HIV incidence in populations at risk for HIV in sub-Saharan Africa and Thailand. J Acquir Immune Defic Syndr 49: $422-431$.

Kippax S, Race K. 2003. Sustaining safe practice: Twenty years on. Soc Sci Med 57: 1-12.

Koblin B, Chesney M, Coates TJ, for the EXPLORE Study Team. 2004. Effects of a behavioural intervention to reduce acquisition of HIV infection among men who have sex with men: The EXPLORE randomised controlled study. Lancet 364: 41-50.

Kong X, Kigozi G, Ssempija V, Serwadda D, Nalugoda F, Makumbi F, Lutako T, Watya S, Wawer M, Gray R. 2011. Longer-term effects of male circumcision on HIV incidence and risk behaviors during post-trial surveillance in Rakai, Uganda. 18th Conference on Retroviruses and Opportunistic Infections (CROI 2011), Boston, February 27-March 2. Abstract 36.

Kranzer K, Zeinecker J, Ginsberg P, Orrell C, Kalaw NN, Lawn SD, Bekker L-G, Wood R. 2010. Linkage to HIV care and antiretroviral therapy in Cape Town, South Africa. PLoS One 5: e13801. doi: 10.1371/journal.pone. 0013801.

Laga M, Alary M, Nzila N, Manoka AT, Tuliza M, Behets F, Goeman J, St Louis M, Piot P. 1994. Condom promotion, sexually transmitted diseases treatment, and declining incidence of HIV-1 infection in female Zairian sex workers. Lancet 344: 246-248.

Lampinen TM, Critchlow CW, Kuypers JM, Hurt CS, Nelson PJ, Hawes SE, Coombs RW, Holmes KK, Kiviat NB. 2000. Association of antiretroviral therapy with detection of HIV-1 RNA and DNA in the anorectal mucosa of homosexual men. AIDS 14: F69-F75.

Legakos S, Gable A. 2008. Challenges to HIV preventionSeeking effective measures in the absence of a vaccine. N Engl J Med 358: 1543-1545.

Lurie MN, Williams B, Zuma K, Mkaya-Mwamburi D, Garnett G, Sturm AW, Sweat MD, Gittelsohn J, Abdool Karim SS. 2003. The impact of migration on HIV-1 transmission in South Africa. Sex Transm Dis 30: 149-156.

Lyle CD, Routson LB, Seaborn GB, Dixon LG, Bushar HF Cyr WH. 1997. An in vitro evaluation of condoms as barriers to a small virus. Sex Transm Dis 24: 161-164.

Mathers B, Degenhardt L, Phillips B, Wiessing L, Hickman M, Strathdee S, Wodak A, Panda S, Tyndall M, Toufik A, et al. 2008. Global epidemiology of injecting drug use and HIV among people who inject drugs: A systematic review. Lancet 372: 1733-1745.

Matovu JK, Makumbi FE. 2007. Expanding access to voluntary HIV counselling and testing in sub-Saharan Africa: Alternative approaches for improving uptake, 20012007. Trop Med Int Health 12: 1315-1322.

McCoombe SG, Short RV. 2006. Potential HIV-1 target cells in the human penis. AIDS 20: 1491-1495.

Merson M, Padian N, Coates TJ, Gupta GR, Bertozzi SM, Piot P, Mane P, Barton M. Lancet HIV Prevention Series authors. 2008. Combination HIV prevention. Lancet 372: 1805-1806.

Metzger DS, Navaline H, Woody GE. 1999. Drug abuse treatment as AIDS prevention. Public Health 113: 97-106.

Microbicide Trials Network. 2011. Researchers reformulate tenofovir vaginal gel for rectal use. http://www.mtnstopshiv.org/node/2934..

Moses S, Bradley JE, Nagelkerke NJ, Ronald AR, NdinyaAchola JO, Plummer FA. 1990. Geographical patterns of male circumcision practices in Africa: Association with HIV seroprevalence. Int J Epidemiol 19: 693-697.

Musicco M, Lazzarin A, Nicolosi A, Gasparini M, Costigliola P, Arici C, Saracco A. 1994. Antiretroviral treatment of men infected with human immunodeficiency virus 
L.-G. Bekker et al.

type 1 reduces the incidence of heterosexual transmission. Italian Study Group on HIV Heterosexual Transmission. Arch Intern Med 154: 1971-1976.

Myron S, Cohen YQ, Chen M, McCauley T, Gamble MC, Hosseinipour N, Kumarasamy JG, Hakim J, Kumwenda J, Grinsztejn B, et al. 2011. Prevention of HIV-1 infection with early antiretroviral therapy. $N$ Engl J Med 365: 493-505.

Nabel GJ. 2001. Challenges and opportunities for development of an AIDS vaccine. Nature 410: 1002-1007.

Nagot N, Ouedraogo A, Foulongne V, Konaté I, Weiss HA, Vergne L, Defer M-C, Djagbaré D, Sanon A, Andonaba J-B, et al. 2007. Reduction of HIV-1 RNA levels with therapy to suppress herpes simplex virus. $N$ Engl J Med 356: 790-799.

Over M. 1998. The effect of societal variables on urban rates of HIV infection in developing countries: An exploratory analysis. In Confronting AIDS: The evidence from the developing world (ed. Ainsworth M, et al.), pp. 39-51. World Bank, Washington, DC.

Padian N, Buve A, Balkus J, Serwadda D, Cates W. 2008. Biomedical intervention to prevent HIV infection: Evidence, challenges, and way forward. Lancet 372: 585-599.

Padian N, McCoy S, Balkus J, Wasserheit J. 2010. Weighing the gold in the gold standard: Challenges in HIV prevention research. AIDS 24: 621-635.

Patterson BK, Landay A, Siegel JN, Flener Z, Pessis D, Chaviano A, Bailey RC. 2002. Susceptibility to human immunodeficiency virus-1 infection of human foreskin and cervical tissue grown in explant culture. Am J Patho 161: $867-873$.

Patterson TL, Mausbach B, Lozada R, Staines-Orozco H, Semple SJ, Fraga-Vallejo M, Orozovich P, Abramovitz D, de la Torre A, Amaro H, et al. 2008. Efficacy of a brief behavioral intervention to promote condom use among female sex workers in Tijuana and Ciudad Juarez, Mexico. Am J Public Health 98: 2051-2057.

PEPFAR. 2008. Prevention for positives. http://www.pepfar.gov/press/92934.htm (accessed April 24, 2008).

Pepin J, Plummer FA, Brunham RC. 1989. The interaction of HIV infection and other sexually transmitted diseases: An opportunity for intervention. AIDS 3: 3-9.

Pinkerton SD, Abramson PR. 1997. Effectiveness of condoms in preventing HIV transmission. Soc Sci Med 44: 1303-1312.

Piot P, Bartos M, Larson H, Zewdie D, Mane P. 2008. Coming to terms with complexity: A call to action for HIV prevention. Lancet 372: 845-859.

Porco TC, Martin JN, Page-Shafer KA, Cheng A, Charlebois E, Grant RM, Osmond DH. 2004. Decline in HIV infectivity following the introduction of highly active antiretroviral therapy. AIDS 18: $81-88$.

Prata N, Vahidnia F, Fraser A. 2005. Gender and relationship differences in condom use among 15-24-year-olds in Angola. Int Fam Plan Perspec 31: 192-199.

Quinn TC, Wawer MJ, Sewankambo N, Serwadda D, Li C, Wabwire-Mangen F, Meehan MO, Lutalo T, Gray RH. 2000. A study in rural Uganda of heterosexual transmission of human immunodeficiency virus. $N$ Engl J Med 343: 364.
Rehle T, Hallett T, Shisana O, Pillay-van Wyk V, Zuma K, Carrara H, Jooste S. 2010. A decline in new HIV infections in South Africa: Estimating HIV incidence from three national HIV surveys in 2002, 2005 and 2008. PLoS One 5: e11094.

Rerks-Ngarm S, Pitisuttithum P, Nitayaphan S, Kaewkungwal J, Chiu J, Paris R, Nakorn P, Namwat C, de Souza M, Adams E, et al. 2009. Vaccination with ALVAC and AIDSVAX to prevent HIV-1 infection in Thailand. $N$ Engl J Med 361: 2209-2220.

Reynolds SJ, Shepherd ME, Risbud AR, Gangakhedkar RR, Brookmeyer RS, Divekar AD, Mehendale SM, Bollinger RC. 2004. Male circumcision and risk of HIV-1 and other sexually transmitted infections in India. Lancet 363: 1039-1040.

Ross DA, Changalucha J, Obasi A, Todd J, Plummer ML, Cleopas-Mazige B, Anemona A, Everett D, Weiss HA, Mabey DC, et al. 2007. Biological and behavioral impact of an adolescent sexual health intervention in Tanzania: A community-randomized trial. AIDS 21: 1943-1955.

Rottingen J-A, Cameron D, Garnett G. 2001. A systematic review of the epidemiologic interactions between classic sexually transmitted diseases and HIV. How much really is known? Sex Transm Dis 28: 579-597.

Schneider JA, Lakshmi V, Dandona R, Kumar GA, Sudha T, Dandona L. 2010. Population-based seroprevalence of HSV-2 and syphilis in Andhra Pradesh state of India. N Engl J Med 362: 427-439.

Shisana O, Rehele T, Simbayi L, Zuma K, Jooste S. 2009 South African national prevalence, incidence, behaviour and communication survey, 2008. In A turning tide among teenagers?, HSRC, Cape Town, South Africa.

Shugars DC, Slade GD, Patton LL, Fiscus SA. 2000. Oral and systemic factors associated with increased levels of human immunodeficiency virus type 1 RNA in saliva. Oral Surg Oral Med Oral Pathol Oral Radiol Endod 89: $432-440$.

Slutkin G, Okware S, Naamara W, Sutherland D, Flanagan D, Carael M, Blas E, Delay P, Tarantola D. 2006. How Uganda reversed its HIV epidemic. AIDS Behav 10: 351-360.

Stamm WE, Handsfield HH, Rompalo AM, Ashley RL, Roberts PL, Corey L. 1988. The association between genital ulcer disease and acquisition of HIV infection in homosexual men. JAMA 260: 1429-1433.

Stoneburner RL, Low-Beer D. 2004. Population-level HIV declines and behavioral risk avoidance in Uganda. Science 304: 714-718.

Strathdee S, Hallett T, Bobrova N, Rhodes T, Booth R, Abdool R, Hankins CA. 2010. HIV and the risk environment among people who inject drugs: Past, present, and projections for the future. Lancet 376: 268-284.

Sumartojo E, Doll L, Holtgrave D, Gayle H, Merson M. 2000. Enriching the mix: Incorporating structural factors into HIV prevention. AIDS 14: S1.

Sweat M, Gregorich S, Sangiwa G, Furlonge C, Balmer D, Kamenga C, Grinstead O, Coates T. 2000. Costeffectiveness of voluntary HIV-1 counselling and testing in reducing sexual transmission of HIV-1 in Kenya and Tanzania. Lancet 356: 113-121.

The Voluntary HIV-1 Counseling Testing Efficacy Study Group. 2000. Efficacy of voluntary HIV-1 counselling 
and testing in individuals and couples in Kenya, Tanzania, and Trinidad: A randomised trial. Lancet 356: $103-$ 112.

Thomsen SC, Ombidi W, Toroitich-Ruto C, Wong EL, Tucker HO, Homan R, Kingola N, Luchters S. 2006. A prospective study assessing the effects of introducing the female condom in a sex worker population in Mombasa, Kenya. Sex Transm Infect 82: 397-402.

Tovanabutra S, Robison V, Wongtrakul J, Sennum S, Suriyanon V, Kingkeow D, Kawichai S, Tanan P, Duerr A, Nelson KE, et al. 2002. Male viral load and heterosexual transmission of HIV-1 subtype E in northern Thailand. J Acquir Immune Defic Syndr 29: 275-283.

UNAIDS. 2000. Evaluation of the $100 \%$ condom programme in Thailand, case study. Geneva: Joint United Nations Programme on HIV/AIDS.

UNAIDS. 2006. Report on the global AIDS epidemic. Geneva.

UNAIDS. 2007. AIDS epidemic update. Geneva: Joint United Nations Programme on HIV/AIDS.

UNAIDS. 2008. Report for the global AIDS epidemic. UNAIDS, Geneva.

UNAIDS. 2009. Condoms and HIV prevention: Position statement by UNAIDS, UNFPA and WHO. Geneva.

UNAIDS/WHO. 2004. UNAIDS/WHO policy statement on HIV testing. Geneva, Switzerland.

UNAIDS and WHO. 2007. New data on male circumcision and HIV prevention: Policy and programme implications; WHO/UNAIDS technical consultation male circumcision and HIV prevention: Research implications for policy and programming Montreux. Geneva: Joint United Nations Programme on HIV/AIDS and World Health Organization.

UNFPA. 2007. Donor support for contraceptives and condoms for STI/HIV prevention. Geneva.

Vandenbruaene M. 2007. King Kennard Holmes-Chair of the Department of Global Health of the University of Washington. Lancet Infect Dis 7: 516-520.

van Schaik N, Kranzer K, Wood R, Bekker LG. 2010. Earlier HIV diagnosis-are mobile services the answer? $S$ Afr Med J 100: 671-674.

Vernazza PL, Troiani L, Flepp MJ, Cone RW, Schock J, Roth F, Boggian K, Cohen MS, Fiscus SA, Eron JJ. 2000. Potent antiretroviral treatment of HIV-infection results in suppression of the seminal shedding of HIV. The Swiss HIV Cohort Study. AIDS 14: 117-121.

Vogel UF. 2007. Towards universal access to prevention, treatment and care: Experiences and challenges from the Mbeya region in Tanzania-A case study. In UNAIDS best practices collection. Joint United Nations Programme on HIV/AIDS, Geneva.

Walensky RP, Wood R, Fofana MO, Martinson NA, Losina E, April MD, Bassett IV, Morris BL, Freedberg KA, Paltiel $\mathrm{AD}$, et al. 2009. The clinical impact and cost-effectiveness of routine, voluntary HIV screening in South Africa. $J$ Acquir Immune Defic Syndr 56: 26-35.
Watson-Jones D, Weiss HA, Rusizoka M, Changalucha J, Baisley K, Mugeye K, Tanton C, Ross D, Everett D, Clayton T, et al. 2008. Effect of herpes simplex suppression on incidence of HIV among women in Tanzania. $N$ Engl J Med 358: 1560-1571.

Wawer MJ, Makumbi F, Kigozi G, Serwadda D, Watya S, Nalugoda F, Buwembo D, Ssempijja V, Kiwanuka N, Moulton LH, et al. 2009. Circumcision in HIV-infected men and its effect on HIV transmission to female partners in Rakai, Uganda: A randomised controlled trial. Lancet 374: 229-237.

Weir SS, Fox LJ, De Moya A, Gomez B, Guerrero G, Hassiq SE. 1998. Measuring condom use among sex workers in the Dominican Republic. Int J STD AIDS 223-226.

Weiss HA, Quigley MA, Hayes RJ. 2000. Male circumcision and risk of HIV infection in sub-Saharan Africa: A systematic review and meta-analysis. AIDS 14: 2361-2370.

Weiss HA, Thomas SL, Munabi SK, Hayes RJ. 2006. Male circumcision and risk of syphilis, chancroid, and genital herpes: A systematic review and meta-analysis. Sex Transm Infect 82: 101-109.

Weller S, Davis K2002. Condom effectiveness in reducing heterosexual HIV transmission. Cochrane DB Syst Rev 1: CD003255.

Westercamp N, Bailey RC. 2007. Acceptability of male circumcision for prevention of HIV/AIDS in sub-Saharan Africa: A review. AIDS Behav 11: 341-355.

WHA 5515. 2002. Small pox eradication-destruction of stocks. Fifty-Fifth World Assembly Agenda item 13,16;18 May 2002.

WHO. 2009. Towards universal access: scaling up priority HIV/AIDS interventions in the health sector: Progress report 2009. Geneva, Switzerland.

Wilson D, Halperin D. 2008. "Know your epidemic, know your response": A useful approach, if we get it right. Lancet 372: $423-426$.

Winkelstein W Jr, Samuel M, Padian NS, Wiley JA, Lang W, Anderson RE, Levy JA. 1987. The San Francisco Men's Health Study: III. Reduction in human immunodeficiency virus transmission among homosexual/bisexual men, 1982-86. Am J Public Health 77: 685-689.

Winkelstein W Jr, Wiley JA, Padian NS, M Samuel M, Shiboski S, Ascher MS, Levy JA, et al. 1988. The San Francisco Men's Health Study: Continued decline in HIV seroconversion rates among homosexual/bisexual men. Am J Public Health 78: 1472-1474.

Wolfe D, Carrieri P, Shepard D, Walker D. 2010. Treatment and care for HIV-infected injecting drug users: A review of barriers and ways forward. Lancet 376: 355-366.

Zuckerman RA, Lucchetti A, Whittington WL, Sanchez J, Coombs RW, Zuñiga R, Magaret AS, Wald A, Corey L, Celum C, et al. 2007. Herpes simplex virus (HSV) suppression with valacyclovir reduces rectal and blood plasma HIV-1 levels in HIV-1/HSV-2-seropositive men: A randomized, double-blind, placebo-controlled crossover trial. J Infect Dis 196: 1500-1508. 


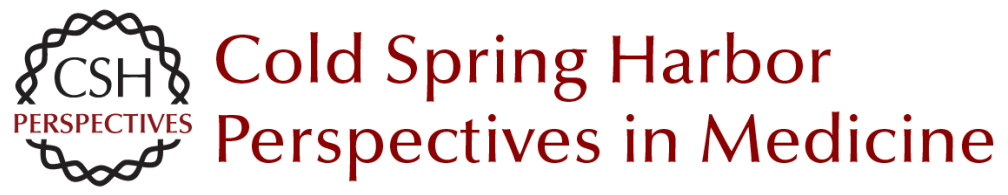

\section{Behavioral and Biomedical Combination Strategies for HIV Prevention}

Linda-Gail Bekker, Chris Beyrer and Thomas C. Quinn

Cold Spring Harb Perspect Med 2012; doi: 10.1101/cshperspect.a007435 originally published online March 27, 2012

\section{Subject Collection HIV}

HIV Pathogenesis: Dynamics and Genetics of

Viral Populations and Infected Cells John Coffin and Ronald Swanstrom

Human Immunodeficiency Virus Vaccine Trials Robert J. O'Connell, Jerome H. Kim, Lawrence Corey, et al.

HIV Transmission George M. Shaw and Eric Hunter

Novel Cell and Gene Therapies for HIV James A. Hoxie and Carl H. June

Behavioral and Biomedical Combination Strategies for HIV Prevention Linda-Gail Bekker, Chris Beyrer and Thomas C. Quinn

HIV-1 Assembly, Budding, and Maturation Wesley I. Sundquist and Hans-Georg Kräusslich

HIV-1 Assembly, Budding, and Maturation Wesley I. Sundquist and Hans-Georg Kräusslich

Lessons in Nonhuman Primate Models for AIDS Vaccine Research: From Minefields to Milestones Jeffrey D. Lifson and Nancy L. Haigwood
HIV-1 Pathogenesis: The Virus Ronald Swanstrom and John Coffin

The T-Cell Response to HIV Bruce Walker and Andrew McMichael

HIV-1 Reverse Transcription Wei-Shau Hu and Stephen H. Hughes

HIV Pathogenesis: The Host A.A. Lackner, Michael M. Lederman and Benigno Rodriguez

HIV: Cell Binding and Entry Craig B. Wilen, John C. Tilton and Robert W. Doms

Innate Immune Control of HIV Mary Carrington and Galit Alter

HIV DNA Integration Robert Craigie and Frederic D. Bushman HIV-1-Related Central Nervous System Disease: Current Issues in Pathogenesis, Diagnosis, and Treatment Serena Spudich and Francisco González-Scarano

For additional articles in this collection, see http://perspectivesinmedicine.cshlp.org/cgi/collection/ 